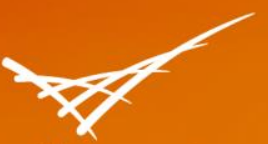

Pacific Northwest

\title{
Texas Residential Energy Code Field Study: Baseline Report
}

\section{${ }^{*}$ April 2017}

\section{R Bartlett \\ M Halverson \\ $\checkmark$ Mendon}

J Hathaway

$Y$ Xie

M Zhao 


\title{
DISCLAIMER
}

This report was prepared as an account of work sponsored by an agency of the United States Government. Neither the United States Government nor any agency thereof, nor Battelle Memorial Institute, nor any of their employees, makes any warranty, express or implied, or assumes any legal liability or responsibility for the accuracy, completeness, or usefulness of any information, apparatus, product, or process disclosed, or represents that its use would not infringe privately owned rights. Reference herein to any specific commercial product, process, or service by trade name, trademark, manufacturer, or otherwise does not necessarily constitute or imply its endorsement, recommendation, or favoring by the United States Government or any agency thereof, or Battelle Memorial Institute. The views and opinions of authors expressed herein do not necessarily state or reflect those of the United States Government or any agency thereof.

\author{
PACIFIC NORTHWEST NATIONAL LABORATORY \\ operated by \\ BATTELLE \\ for the \\ UNITED STATES DEPARTMENT OF ENERGY \\ under Contract DE-AC05-76RL01830
}

Printed in the United States of America
Available to DOE and DOE contractors from the Office of Scientific and Technical Information, P.O. Box 62, Oak Ridge, TN 37831-0062; ph: (865) 576-8401 fax: $(865) 576-5728$
email: reports $a$ adonis.osti.gov
Available to the public from the National Technical Information Service 5301 Shawnee Rd., Alexandria, VA 22312 ph: (800) 553-NTIS (6847) email: orders@ntis.gov <http://www.ntis.gov/about/form.aspx> Online ordering: http://www.ntis.gov




\section{Texas Residential Energy Code Field Study: Baseline Report}

\author{
R Bartlett \\ M Halverson
V Mendon \\ M Halverson
V Mendon
}

\author{
J Hathaway \\ Y Xie \\ M Zhao
}

*April 2017

Prepared for

the U.S. Department of Energy

under Contract DE-AC05-76RL01830

Pacific Northwest National Laboratory

Richland, Washington 99352

*Minor editorial updates made in August 2017 



\section{Executive Summary}

A research project in the state of Texas identified opportunities to reduce homeowner utility bills in residential single-family new construction by increasing compliance with the state energy code. The study was initiated in October 2014; data collection began in March 2015, and continued through October 2015. During this period, research teams visited 133 homes in 30 counties in and around Houston during various stages of construction, resulting in a substantial data set based on observations made directly in the field. Stakeholders in the state agreed that these 30 counties represented the levels of energy codes and enforcement seen across the state. Analysis of the data has led to a better understanding of the energy features present in homes, and, when extrapolated across the entire state, indicates over $\$ 16$ million in potential annual savings to Texas homeowners that could result from increased code compliance. Public and private entities within the state can use this information to justify and catalyze future investments in energy code training and related energy efficiency programs.

\section{Methodology}

The project team was led by the National Association of State Energy Officials (NASEO) with support from the South-central Partnership for Energy Efficiency as a Resource (SPEER) and Cadmus. The team applied a methodology prescribed by the U.S. Department of Energy (DOE), which was based on collecting information for the energy code-required building components with the largest direct impact on energy consumption. These key items are a focal point of the study, and in turn drive the analysis and savings estimates. The project team implemented a customized sampling plan representative of new construction within the state, which was originally developed by Pacific Northwest National Laboratory (PNNL), and then vetted through public meetings with key stakeholders in the state.

Following data collection, PNNL conducted three stages of analysis on the resulting data set (Figure ES.1). The first stage identified compliance trends within the state based on the distributions observed in the field for each key item. The second modeled energy consumption of the homes observed in the field relative to what would be expected if sampled homes just met minimum code requirements. The third stage then calculated the potential energy savings, consumer cost savings, and avoided carbon emissions associated with increased code compliance. Together, these findings provide valuable insight on challenges facing energy code implementation and enforcement, and are intended to inform future energy code education, training and outreach activities.

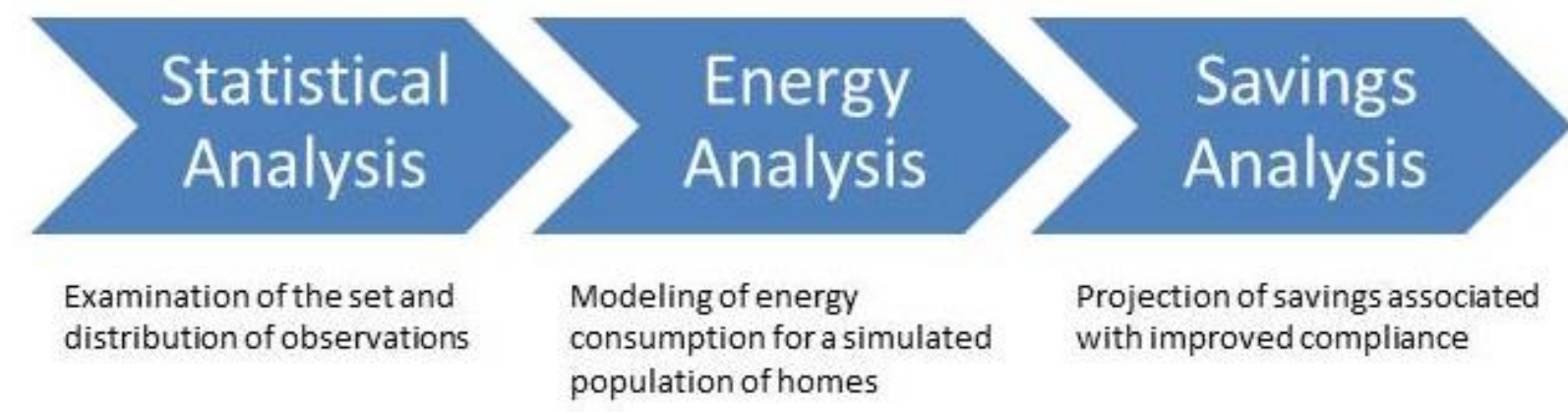

Figure ES.1. Stages of Analysis Applied in the Study

At the time of the study, the state energy code was based on the 2009 International Residential Code (IRC). Following data collection, the state adopted an updated energy code, known as the 2015 Texas 
Energy Code. ${ }^{1}$ Most data in this study was collected from homes permitted under the 2009 code; potential savings, however, were calculated against the 2015 code as that is the code that homes will need to comply with in the future, and that will be the focus of ongoing training within the state. The savings noted in Table ES. 1 and the results noted in Figure ES.2 are the results based on comparison to the 2015 Texas code. For illustrative purposes, some of the results presented in other sections of this report are based on the 2009 IECC $^{2}$, as noted.

\section{Results}

The key items with the greatest potential for savings in Texas are presented below (Table ES.1). The estimates presented in the table represent the savings associated with each measure, and are extrapolated based on projected new construction. These items should be considered a focal point for complianceimprovement programs within the state, including energy code educational, training and outreach initiatives.

Table ES.1. Estimated Annual Statewide Savings Potential in Texas

\begin{tabular}{lccc}
\hline \multicolumn{1}{c}{ Measure } & $\begin{array}{c}\text { Total Energy } \\
\text { Savings (MMBtu) }\end{array}$ & $\begin{array}{c}\text { Total Energy Cost } \\
\text { Savings }(\$)\end{array}$ & $\begin{array}{c}\text { Total State Emissions } \\
\text { Reduction }(\text { MT CO2e) }\end{array}$ \\
\hline Envelope Air Leakage & 314,889 & $4,656,869$ & 24,969 \\
Exterior Wall & 293,040 & $5,029,864$ & 27,865 \\
Insulation & 181,188 & $3,582,893$ & 20,371 \\
Duct Leakage & 70,571 & $2,774,421$ & 17,100 \\
Lighting & 23,677 & 443,058 & 2,496 \\
Ceiling Insulation & $\mathbf{8 8 3 , 3 6 5 ~ M M B t u}$ & $\mathbf{\$ 1 6 , 4 8 7 , 1 0 5}$ & $\mathbf{9 2 , 8 0 1}$ MT CO2e \\
TOTAL & &
\end{tabular}

Simulation analysis of the collected field data indicates an average regulated energy use intensity (EUI) of $20.95 \mathrm{kBtu} / \mathrm{ft}^{2}-\mathrm{yr}$ statewide for the homes that are being built in the state today. This compares favorably to the $25.94 \mathrm{kBtu} / \mathrm{ft}^{2}-\mathrm{yr}$ that would be expected if homes were constructed to just meet the minimum requirements of the 2009 IECC. Put another way, homes being built in the state today use $19 \%$ less energy than expected under the old state code. Compared to the more stringent 2015 Texas code, however, new homes are using 13\% more energy, making it clear that substantial savings opportunities exist as the new code is implemented.

\footnotetext{
${ }^{1}$ The 2015 Texas Energy Code is based on the 2015 International Residential Code with state amendments to modify the Energy Rating Index values and is available at http://seco.cpa.state.tx.us/tbec/singlefam.php.

${ }^{2}$ The baseline code for analysis was the 2009 IECC which was compared to the 2015 Texas Energy Code which is based on the International Residential Code. Using the IECC instead of the IRC as the baseline did not affect the analysis because the key item requirements in the 2009 IECC are equivalent to those in the 2009 IRC. The only exception is the SHGC requirement in climate zone 2 which is 0.35 in the IRC versus 0.30 in the IECC. However, since all SHGC observations met the 0.30 requirement, this difference had no impact on the results.
} 


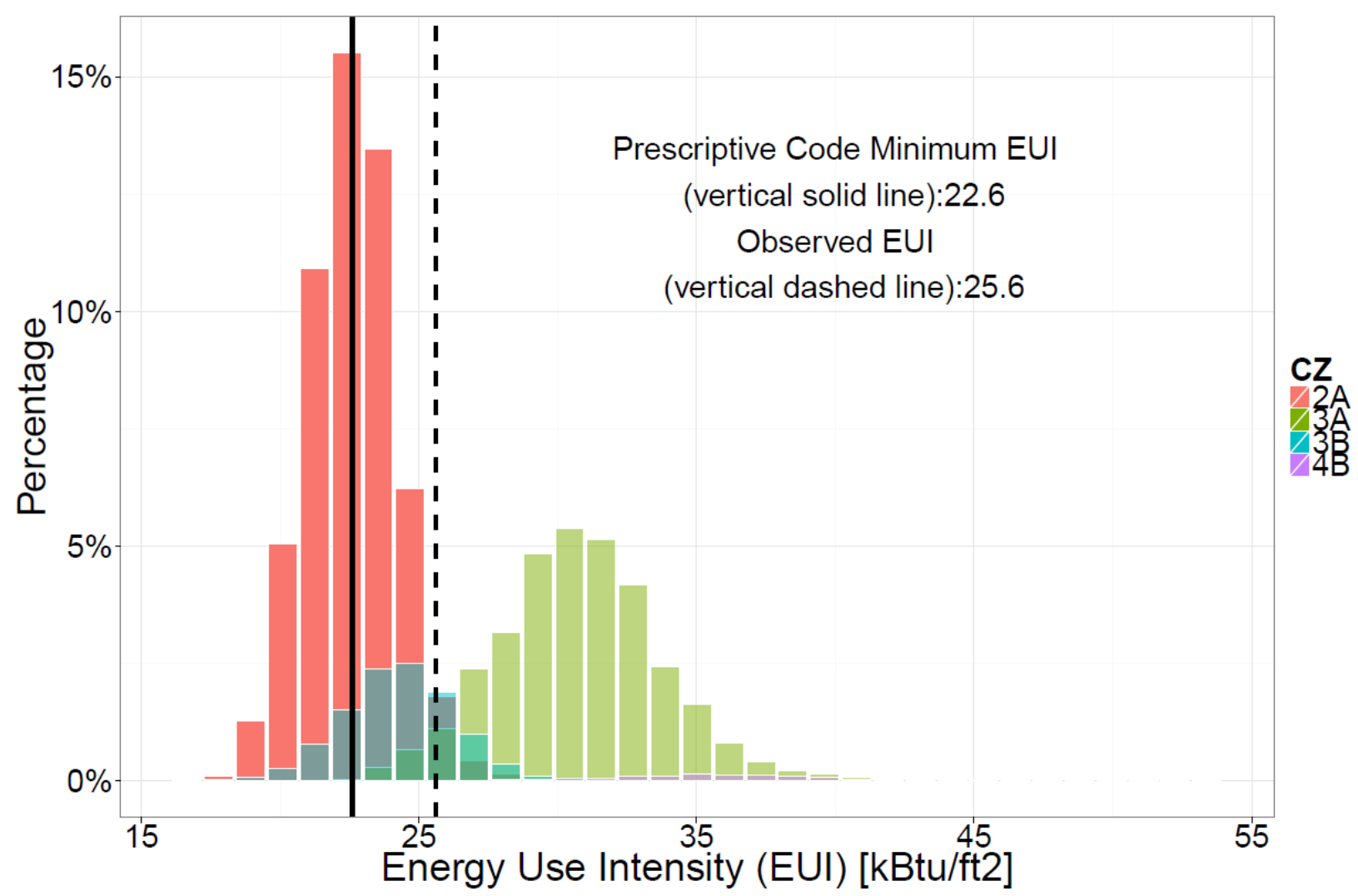

Figure ES.2. Modeled Distribution of Regulated EUI (kBtu/ft²/year) in Texas (2015 TX Code) 



\section{Acknowledgments}

The following members comprised the Texas project team:

- Todd Sims, National Association of State Energy Officials (NASEO)

- Rodney Sobin, National Association of State Energy Officials (NASEO)

- Richard Morgan, South-central Partnership for Energy Efficiency as a Resource (SPEER)

- Chris Herbert, South-central Partnership for Energy Efficiency as a Resource (SPEER)

- Eric Makela, Cadmus Group (Cadmus)

\section{NASEO}

The National Association of State Energy Officials is a national non-profit association for the governordesignated energy officials from each of the 56 states and territories. Formed by the states in 1986, NASEO facilitates peer learning among state energy officials, serves as a resource for and about state energy offices, and advocates the interests of the state energy offices to Congress and federal agencies. For more information on NASEO, visit http://www.naseo.org.

\section{SPEER}

The South-central Partnership for Energy Efficiency as a Resource is a regional energy efficiency organization that aims to accelerate the adoption of advanced building systems and energy efficient products and services in Texas and Oklahoma. For more information, see https://eepartnership.org.

\section{Cadmus}

The Cadmus Group, Inc. was founded in 1983 in Watertown, MA. They provide services in the areas of energy, environment, high performance building, sustainability, public health, and strategic communications. See more information on Cadmus at https://www.cadmusgroup.com/. 



\section{Acronyms and Abbreviations}

\begin{tabular}{|c|c|}
\hline $\mathrm{AC}$ & air conditioning \\
\hline $\mathrm{ACH}$ & air changes per hour \\
\hline AFUE & annual fuel utilization efficiency \\
\hline AHU & air handling unit \\
\hline BOAT & Building Officials Association of Texas \\
\hline Btu & British thermal unit \\
\hline $\mathrm{cfm}$ & cubic feet per minute \\
\hline $\mathrm{CZ}$ & climate zone \\
\hline DOE & U.S. Department of Energy \\
\hline EERE & Office of Energy Efficiency and Renewable Energy \\
\hline ESL & Energy Systems Laboratory of Texas A\&M University \\
\hline EUI & energy use intensity \\
\hline EUMMOT & Electric Utility Marketing Managers of Texas \\
\hline FOA & funding opportunity announcement \\
\hline GHBA & Greater Houston Builders Association \\
\hline ICC & International Code Council \\
\hline IECC & International Energy Conservation Code \\
\hline kBtu & thousand British thermal units \\
\hline MMBtu & million British thermal units \\
\hline MT & metric ton \\
\hline NA & not applicable \\
\hline NASEO & National Association of State Energy Officials \\
\hline NEMA & National Electrical Manufacturers Association \\
\hline PNNL & Pacific Northwest National Laboratory \\
\hline RFI & request for information \\
\hline SECO & Texas State Energy Conservation Office \\
\hline SHGC & solar heat gain coefficient \\
\hline SPEER & South-central Partnership for Energy Efficiency as a Resource \\
\hline TAB & Texas Association of Builders \\
\hline TECC & Texas Energy Code Compliance Collaborative \\
\hline TX & Texas \\
\hline
\end{tabular}





\section{Contents}

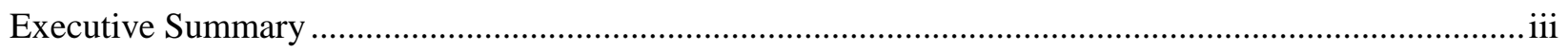

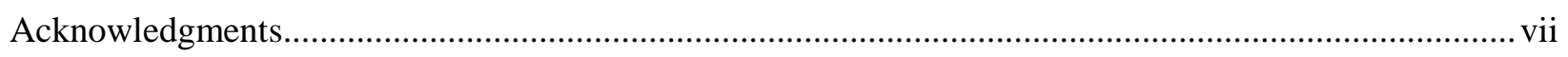

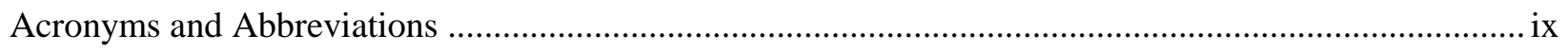

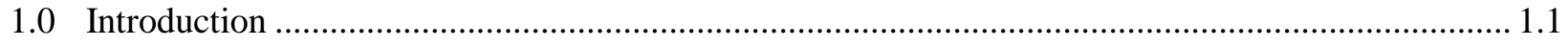

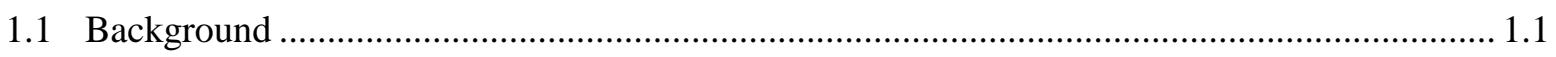

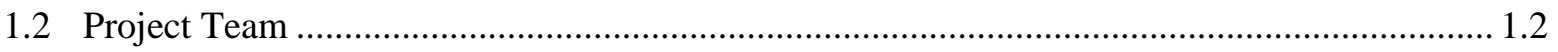

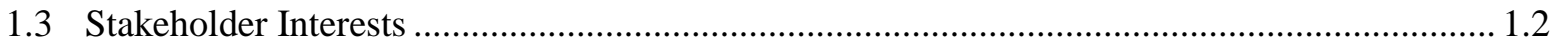

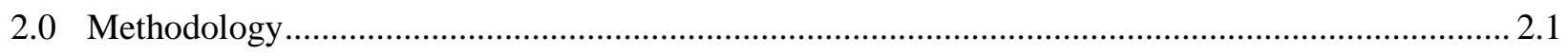

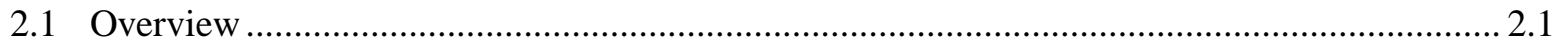

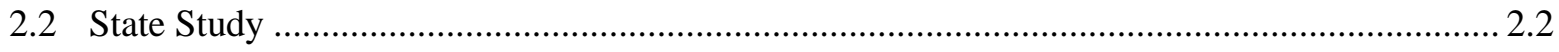

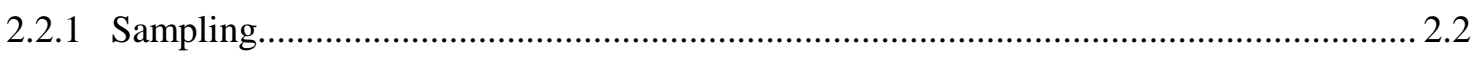

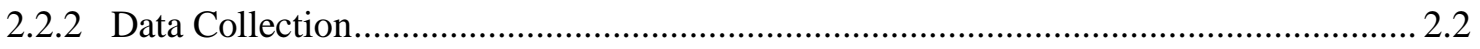

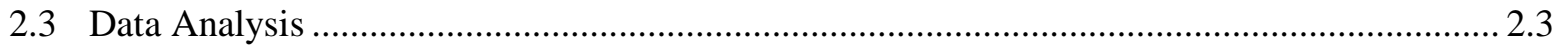

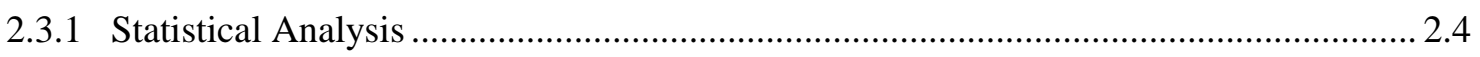

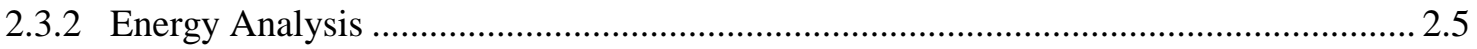

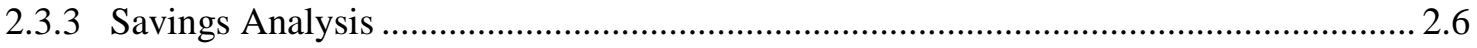

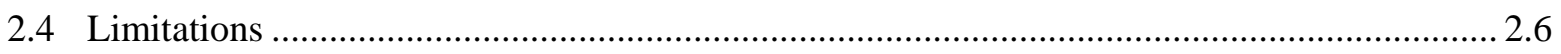

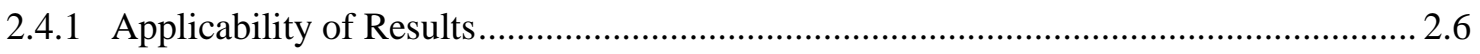

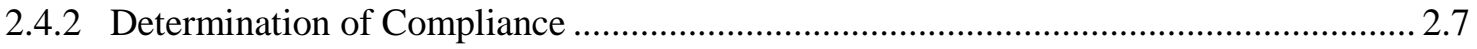

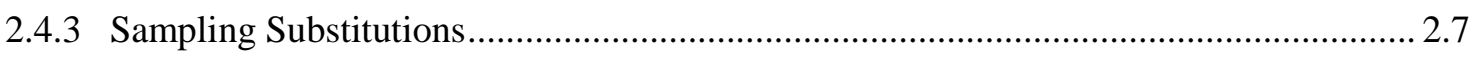

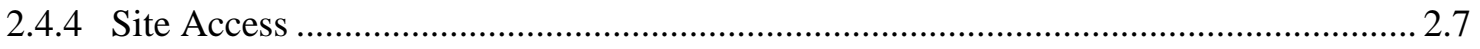

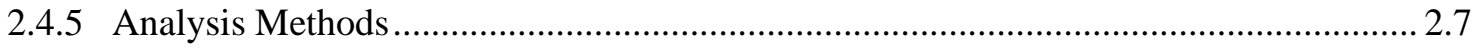

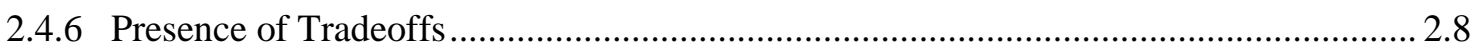

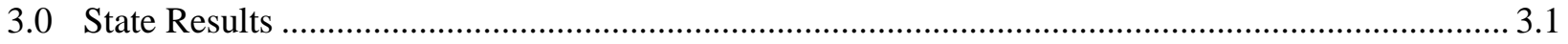

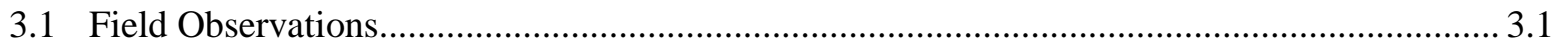

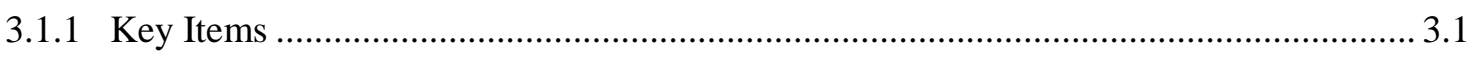

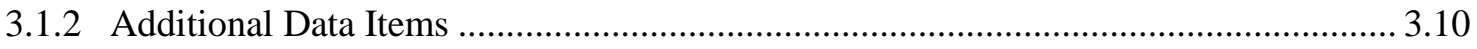

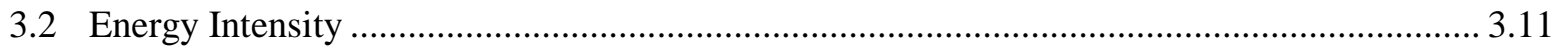

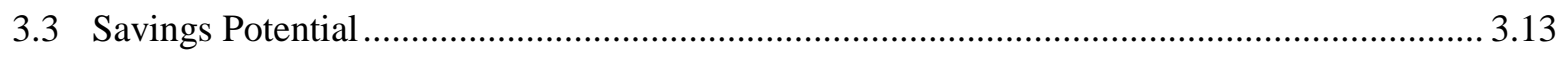

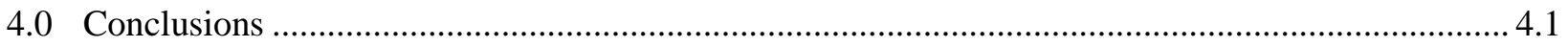

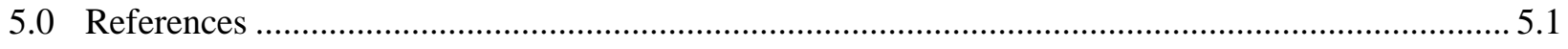

Appendix A - Stakeholder Participation …….......................................................................... A.1

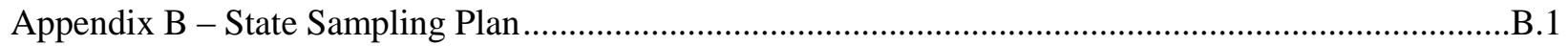

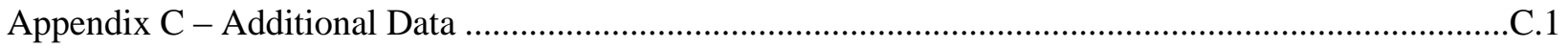




\section{Figures}

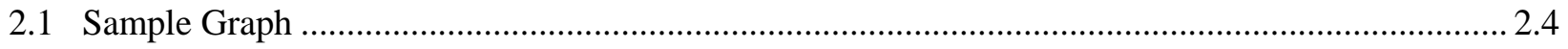

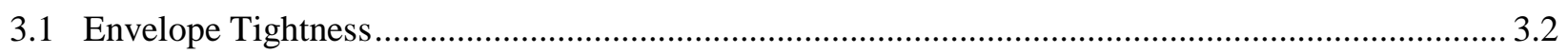

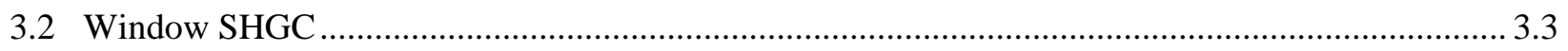

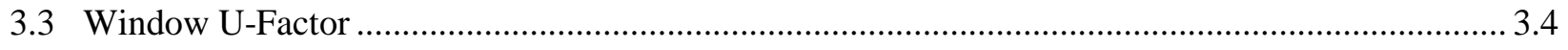

3.4 Texas Wall Assembly Performance, including Wall Insulation Installation Quality ...................... 3.5

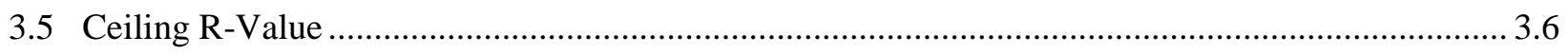

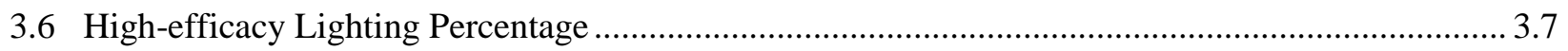

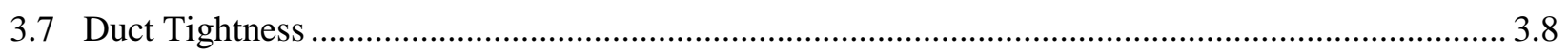

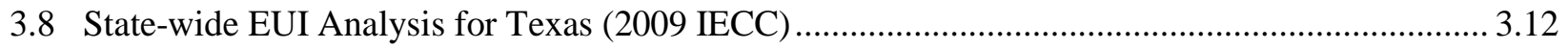

3.9 State-wide EUI Analysis for Texas (2015 TX Code) …............................................................. 3.12

\section{Tables}

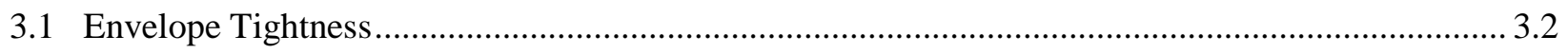

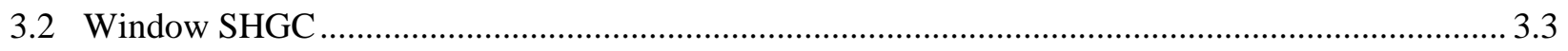

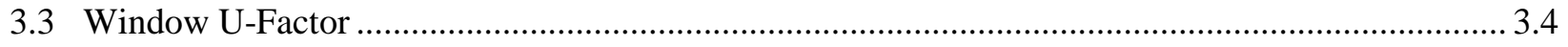

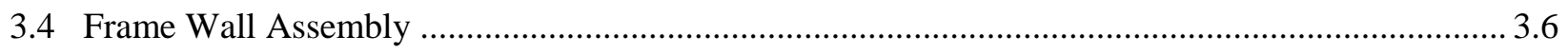

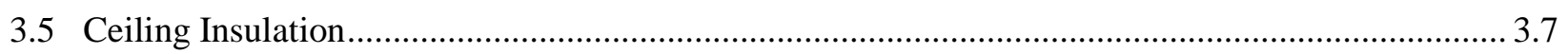

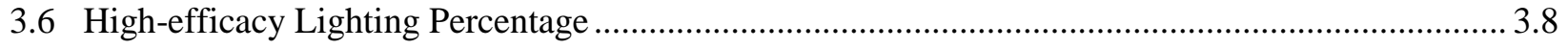

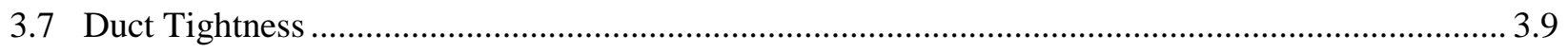

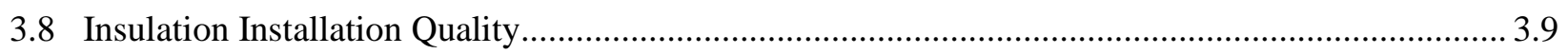

3.9 Statewide Annual Measure-Level Savings for Texas ….................................................................13

3.10 Five-years, Ten-years, and Thirty-years Cumulative Annual Statewide Savings for Texas ........... 3.14

4.1 Annual Statewide Savings Potential in Texas.......................................................................... 4.1 


\subsection{Introduction}

A research project in the state of Texas investigated the energy code-related aspects of unoccupied, newly constructed, single family homes across the state. The study followed a DOE-prescribed methodology, which allowed the project team to build an empirical data set based on observations made directly in the field. The data was then analyzed to identify compliance trends, their impact on statewide energy consumption, and calculate savings that could be achieved through increased code compliance. Study findings can help to justify additional support for energy code education, training \& outreach activities, as well as catalyze future investments in compliance-improvement programs.

The Texas field study was initiated in October 2014; data collection began in March 2015, and continued through October 2015. During this period, research teams visited 133 homes across the state during various stages of construction. At the time of the study, the state energy code was based on the 2009 International Residential Code (IRC) with no amendments. Following data collection, the state proceeded in adopting an updated energy code, known as the 2015 Texas Energy Code. ${ }^{1}$ Most data in this study was collected from homes permitted under the $2009 \operatorname{code}^{2}$; however, potential savings were calculated against the 2015 code as that is what future homes are required to comply with.

\subsection{Background}

The data collected and analyzed for this report was in response to the U.S. Department of Energy (DOE) Funding Opportunity Announcement (FOA), "Strategies to Increase Residential Energy Code Compliance Rates and Measure Results". ${ }^{3}$ The goal of the FOA is to determine whether an investment in education, training, and outreach programs can produce a significant, measurable change in single-family residential building code energy use, and therefore energy savings, within 2-3 years. Participating states are:

- Conducting a baseline field study to determine installed energy values of code-required items, identify issues, and calculate savings opportunities;

- Implementing education, training, and outreach activities designed to increase code compliance; and

- Conducting a second field study to measure the post-training values using the same methodology as the baseline study.

Energy codes for residential buildings have advanced significantly in recent years, with today's model codes approximately $30 \%$ more efficient than codes adopted by the majority of U.S. states. ${ }^{4,5}$ Hence, the importance of ensuring code-intended energy savings, so that consumers reap the benefits of improved codes - something which will happen only through high levels of compliance. More information on the FOA and overall DOE interest in compliance is available on the DOE Building Energy Codes Program website. $^{6}$

\footnotetext{
${ }^{1}$ The 2015 Texas Energy Code is based on the 2015 International Residential Code with state amendments to modify the Energy Rating Index values and is available at http://seco.cpa.state.tx.us/tbec/singlefam.php.

${ }^{2}$ Some homes in the Houston area were permitted under the 2012 IECC.

${ }^{3}$ Available at https://www.energycodes.gov/compliance/residential-energy-code-field-study

${ }^{4}$ National Energy and Cost Savings for New Single- and Multifamily Homes: A Comparison of the 2006, 2009, and 2012 Editions of the IECC, available at http://www.energycodes.gov/development

${ }_{6}^{5}$ Available at http://www.energycodes.gov/adoption/states

${ }^{6}$ Available at https://www.energycodes.gov/compliance
} 


\subsection{Project Team}

The Texas project was led by the National Association of State Energy Officials (NASEO), with support from the South-central Partnership for Energy Efficiency as a Resource (SPEER), and field data collected by Cadmus. The Pacific Northwest National Laboratory (PNNL) defined the methodology, conducted data analysis, and provided technical assistance to the project team. Funding and overall program direction was provided by the DOE Building Energy Codes Program as part of a broader initiative being conducted across several U.S. states. More information on the organizations comprising the project team is included in the Acknowledgements section of this report.

\subsection{Stakeholder Interests}

The project started with the formation of a stakeholder group comprised of interested and affected parties within the state. Following an initial kickoff meeting, the project team maintained active communication with the stakeholders throughout the course of the project. Stakeholders were sought from the following groups:

- Building officials

- Homebuilders

- Subcontractors

- Material supply distributors

- Government agencies

- Energy efficiency advocates

- Utilities

- Other important entities identified by the project team

A description of the stakeholders who participated in the project to date is included in Appendix A.

Members of these and other groups are critical to the success of the project, as they hold important information (e.g., building officials have the lists of homes under construction and are therefore key to the sampling process), control access to homes needed for site visits, are targets for training, or, as is often the case with government agencies, have oversight responsibilities for code adoption and implementation. Utilities were also identified as a crucial stakeholder, and often have direction from state regulatory bodies (e.g., the public utility commission) to achieve energy savings. Many utilities have expressed an increasing interest in energy code investments, and are looking at energy code compliance as a means to provide assistance and generate additional savings. The field study is aimed specifically at providing a strong, empirically-based case for such utility investment. 


\subsection{Methodology}

\subsection{Overview}

The Texas field study was based on a methodology developed by DOE to identify savings opportunities associated with increased energy code compliance. This methodology involves gathering field data on energy code measures, as installed and observed in actual homes. In the following analysis, trends and issues are identified, which can help inform energy code training and other compliance-improvement programs.

Highlights of the methodology:

- Focuses on individual code requirements within new single-family homes

- Based on a single site visit to reduce burden and minimize bias

- Prioritizes key items with the greatest impact on energy consumption

- Designed to produce statistically significant results

- Data confidentiality built into the experiment—no occupied homes were visited, and no personal data shared

- Results based on an energy metric and reported at the state level

PNNL identified the code-requirements (and associated energy efficiency measures) with the greatest direct impact on residential energy consumption. ${ }^{1}$ These key items drive sampling, data analysis, and eventual savings projections:

1. Envelope tightness (ACH at 50 Pascals)

2. Window SHGC

3. Window U-factor

4. Exterior wall insulation (assembly U-factor)

5. Ceiling insulation (R-value)

6. Lighting (\% high-efficacy)

7. Foundation insulation (R-value $)^{2}$

8. Duct tightness (expressed in cfm per $100 \mathrm{ft}^{2}$ of conditioned floor area at 25 Pascals)

PNNL evaluated the variability associated with each key item, and concluded that a minimum of 63 observations would be needed for each one to produce statistically significant results at the state level. Both the key items themselves and the required number of observations were prescribed in the DOE methodology.

The following sections describe how the methodology was implemented as part of the Texas study, including sampling, data collection, and resulting data analysis. More information on the DOE data

\footnotetext{
${ }^{1}$ Based on the mandatory and prescriptive requirements of the International Energy Conservation Code (IECC)

${ }^{2}$ Floor insulation, basement wall insulation, crawlspace wall insulation, and slab insulation are combined into a single category of foundation insulation
} 
collection and analysis methodologies is published separately from this report (DOE 2016) and is available on the DOE Building Energy Codes Program website. ${ }^{3}$

\subsection{State Study}

The prescribed methodology was customized for the State of Texas to reflect circumstances unique to the state, such as state-level code requirements and regional construction practices. Customization also ensured that the results of the study would have credibility with stakeholders.

\subsubsection{Sampling}

Given both the large geographic size and population of Texas, the project team decided to limit data collection to an area comprising 30 counties in south central and southeast Texas anchored on Houston (all climate zone 2). It includes dense metropolitan areas, small- to mid-size cities and towns and unincorporated areas of counties and has a population of approximately 7 million, about $25 \%$ of the state population.

An initial sample plan for the area was first developed by PNNL, and then vetted by stakeholders within the state. For purposes of the study, stakeholders agreed that this area could be used to represent the entire state as it includes a broad range of the energy codes in use and levels of enforcement seen across the state. The samples were apportioned to individual jurisdictions in proportion to their average level of construction over the past three years compared to the overall construction activity in the 30 counties ${ }^{4}$. This approach is known as a proportional random sample. The plan specified the number of key item observations required in each selected jurisdiction (totaling 63 of each key item for the 30-county area). The sample taken in the 30-county area was also adjusted so that the ratio of urban to rural areas was similar to the overall state ratio. See Section 2.4 Limitations under Applicability of Results for additional discussion of how the data collected in CZ2A was applied to the entire state.

Special considerations were discussed by stakeholders at the project kickoff meeting, such as statespecific construction practices and systematic differences across county or climate zone boundaries. These considerations were taken into account and incorporated into the final statewide sample plan shown in Appendix B.

\subsubsection{Data Collection}

Following confirmation of the sample plan, the project team began contacting local building departments to identify homes currently in the permitting process. Code officials responded by providing a list of homes at various stages of construction within their jurisdiction. These lists were then sorted using a random number generator and utilized by the team's field personnel to select specific homes to visit and call the builder to gain site access. As prescribed by the methodology, each home was visited only once to avoid any bias associated with multiple site visits. Only items directly observed by the field teams during site visits were recorded. If access was denied for a particular home on the list, field personnel moved onto the next home on the list.

\footnotetext{
${ }^{3}$ Available at https://www.energycodes.gov/compliance/residential-energy-code-field-study

${ }^{4}$ Available at http://censtats.census.gov/ (select the "Building Permits" data)
} 


\subsubsection{Data Collection Form}

The field teams relied on a data collection form customized to the mandatory and prescriptive requirements of the state energy code (2009IRC) $)^{5}$. The final Texas data collection form is available in spreadsheet format on the DOE Building Energy Codes Program website. ${ }^{6}$ The form included all energy code requirements (i.e., not just the eight key items), as well as additional items required under the prescribed methodology. For example, the field teams were required to conduct a blower door test and duct leakage test on every home where such tests could be conducted, using RESNET $^{7}$ protocols.

Field teams gathered substantial information beyond the key items, much of which was used during various phases of the analysis, or to supplement the overall study findings. For example, insulation installation quality impacts the energy-efficiency of insulation, itself, and is therefore used to modify that key item within the later energy modeling and savings calculation. Observed equipment (e.g., fuel type and efficiency rating) and basic home characteristics (e.g., foundation type) help validate the prototype models applied during energy simulation. Other questions, such as whether the home participated in an above-code program, can also assist in understanding whether there may be other influencing factors at play beyond the code requirements.

The data collected were the energy values observed, rather than the compliance status. For insulation, for example, the R-value was collected, for windows the U-factor. The alternative, such as was used in DOE's older work, simply stated whether an item complied (e.g., via a yes/no response). The current approach provides an improved understanding of how compliance equates to energy consumption and gives much more flexibility during analysis since the field data can be compared to any energy code.

\subsubsection{Data Management and Availability}

Once the data collection effort was complete, the project team conducted a thorough quality assurance review. This review included an independent check of raw data compared to the information provided to PNNL for analysis, and helped to ensure the completeness, accuracy and consistency across the inputs. Prior to submitting the data to PNNL, the team also removed all personally identifiable information, such as project site locations and contact information. The final dataset is available in spreadsheet format on the DOE Building Energy Codes Program website. ${ }^{8}$

\subsection{Data Analysis}

All data analysis in the study was performed by PNNL, and was applied through three basic stages:

1. Statistical Analysis: Examination of the set and distribution of observations for individual measures

2. Energy Analysis: Modeling of energy consumption for a simulated population of homes

3. Savings Analysis: Projection of savings associated with improved compliance

\footnotetext{
${ }^{5}$ Several questions were removed as they were not applicable to Texas: basements and crawlspaces, slab insulation, and snow and ice melting systems.

${ }^{6}$ Available at https://www.energycodes.gov/compliance/residential-energy-code-field-study based on the forms typically used by the REScheck compliance software.

${ }^{7}$ See http://www.resnet.us/standards/RESNET_Mortgage_Industry_National_HERS_Standards.pdf

${ }^{8}$ Available at https://www.energycodes.gov/compliance/residential-energy-code-field-study
} 
The first stage identified compliance trends within the state based on what was observed in the field for each key item. The second modeled energy consumption (of the homes observed in the field) relative to what would be expected if sampled homes just met minimum code requirements. The third stage then calculated the potential energy savings, consumer cost savings, and avoided carbon emissions associated with increased code compliance. Together, these findings provide valuable insight on challenges facing energy code implementation and enforcement, and are intended to inform future energy code education, training and outreach activities.

See Section 2.4 Limitations under Applicability of Results for additional discussion of how the data collected in CZ2A was applied to the entire state.

The following sections provide an overview of the analysis methods applied to the field study data, with the resulting state-level findings presented in Section 3.0 (State Results).

\subsubsection{Statistical Analysis}

Standard statistical analysis was performed with distributions of each key item plotted by climate zone. This approach enables a better understanding of the range of data, and provides insight on what energyefficiency measures are most commonly installed in the field. It also allows for a comparison of installed values to the applicable code requirement, and for identification of any problem areas where potential for improvement exists. The graph below represents a sample key item distribution, and is further explained in the following paragraph.

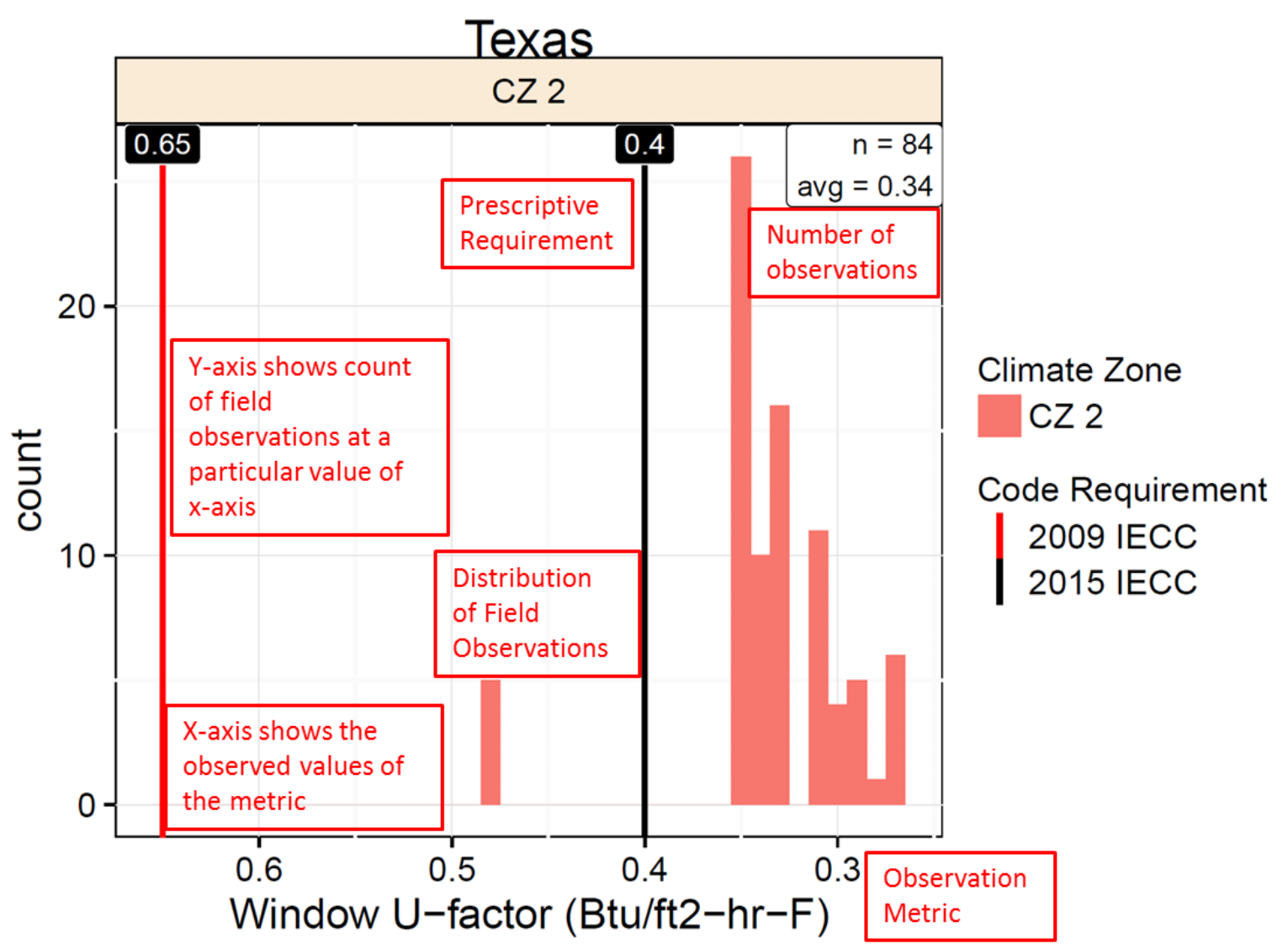

Figure 2.1. Sample Graph 
Each graph is set up in a similar fashion, identifying the state, climate zone, and specific item being analyzed. The total sample size (n) is displayed in the top left or right corner of the graph, along with the distribution average. The metric associated with the item is measured along the horizontal axis (e.g., window U-factor is measured in Btu/ft2-hr-F), and a count of the number of observations is measured along the vertical axis. A vertical line is imposed on the graph representing the applicable code requirement. In this case, the observations are compared to two codes; the red line represents the requirement of the 2009 IECC $^{9}$, and the black line represents the requirement of Texas' amended 2015 IRC - values to the right-hand side of this line are better than code. Values to the left-hand side of this line represent areas for improvement.

\subsubsection{Energy Analysis}

The next phase of the analysis leveraged the statistical analysis results to model average statewide energy consumption. A consequence of the field study methodology allowing only one site visit per home to minimize bias is that a full set of data cannot be gathered on any single home, as not all energy-efficiency measures are in place or visible at any given point during the home construction process. This lack of complete data for individual homes creates an analytical challenge, because energy modeling and simulation protocols require sufficient inputs to generate reliable results. To address this challenge, a series of "pseudo homes" were created, comprised of over 1,500 models encompassing most of the possible combinations of key item values found in the observed field data. In aggregate, the models provide a statistical representation of the state's population of newly constructed homes. This approach is known in statistics as a Monte Carlo analysis.

Energy simulation was then conducted using the EnergyPlus ${ }^{\mathrm{TM}}$ software. ${ }^{10}$ Each of the 1,500 models was run multiple times, to represent each combination of heating systems and foundation types commonly found in the state. This resulted in upwards of 30,000 simulation runs for each climate zone within the state. An EUI was calculated for each simulation run and these results were then weighted by the frequency with which the heating system/foundation type combinations were observed in the field data. Average EUI was calculated based on regulated end uses (heating, cooling, lighting and domestic hot water) for two sets of homes - one as-built set based on the data collected in the field, and a second codeminimum set (i.e., exactly meeting minimum code requirements). Comparing these values provides perspective on whether the population of newly constructed homes in the state is using more or less energy than would be expected based on minimum code requirements.

Further specifics of the energy analysis are available in a supplemental methodology report (DOE 2016). ${ }^{11}$

\footnotetext{
${ }^{9}$ The baseline code for analysis was the 2009 IECC which was compared to the 2015 Texas Energy Code which is based on the International Residential Code. Using the IECC instead of the IRC as the baseline did not affect the analysis because the key item requirements in the 2009 IECC are equivalent to those in the 2009 IRC. The only exception is the SHGC requirement in climate zone 2 which is 0.35 in the IRC versus 0.30 in the IECC. However, since all SHGC observations met the 0.30 requirement, this difference had no impact on the results.

${ }^{10}$ See https://energyplus.net/

${ }^{11}$ Available at https://www.energycodes.gov/compliance/residential-energy-code-field-study
} 


\subsubsection{Savings Analysis}

To begin the third phase, each of the key items was examined to determine those where a significant number of observed values did not meet the associated code requirement ${ }^{12}$. For these items, additional models were then created to assess the savings potential, comparing what was observed in the field to a scenario of full compliance (i.e., where all worse-than-code observations for a particular item exactly met the corresponding code requirement $)^{13}$. This was done by individually upgrading each worse-than-code observation to the corresponding prescriptive code requirement, resulting in a second set of models (full compliance) that could be compared to the first (as built). All other components were maintained at the corresponding prescriptive code value, allowing for the savings potential associated with that key item to be evaluated in isolation.

Once the full compliance models were created, additional energy simulation was carried out using EnergyPlus. All variations of observed heating systems and foundation types were included, and annual electric, gas and total EUIs were extracted for each building. For each key item analyzed, the difference in energy use between the as built and full compliance cases represents the potential energy savings that can theoretically be achieved if all homes met the code minimum. To calculate savings, the differences in energy use calculated for each case are weighted by the corresponding frequency of each observation to arrive at an average energy savings potential for each climate zone. For states with multiple climate zones, potential energy savings for each climate zone are further weighted using construction starts in that zone to obtain the average statewide energy savings potential. State-specific construction volumes and fuel prices are used to calculate the maximum energy savings potential for the state in terms of energy (MMBtu), energy cost (\$), and avoided carbon emissions (MT CO2e).

Note that this approach results in the maximum theoretical savings potential for each measure as it does not take "interaction effects" into account such as the increased amount of heating needed in the winter when energy efficient lights are installed. A building's energy consumption is a dynamic and interactive process that includes all the building components present within a given home. In a typical real building, the savings potential might be higher or lower; however, additional investigation indicated that the relative impact of such interactions is very small, and can safely be ignored without changing the basic conclusions of the analysis.

\subsection{Limitations}

The following sections address limitations of the project, some of which are inherent to the methodology, itself, and other issues as identified in the field.

\subsubsection{Applicability of Results}

An inherent limitation of the study design is that the results are statistically significant only in the geographical region that was sampled; the 30-county area comprising the sample. However, the results were later extrapolated to the entire state at the project team's request. In absence of additional data, data collected in CZ2A were analyzed in CZ3A, CZ3B, and CZ4B assuming that construction trends would remain similar (i.e., observed values from $\mathrm{CZ2A}$ were used as observed values in the other climate zones

\footnotetext{
12 "Significant" was defined as $15 \%$ or more of the observed values not meeting the associated code requirement. Only the items above this threshold were analyzed.

${ }^{13}$ Better-than-code items were not included in this analysis because the intent was to identify the maximum savings potential for each measure. The preceding energy analysis included both better-than-code and worse-than-code results, allowing them to offset each other.
} 
as well). Specifically, the random sampling process was applied to the set of observations in each CZ separately, followed by simulation runs. The state EUI results were derived by aggregating the results of the multiple climate zones-moisture regimes weighted with the $\mathrm{CZ}$ construction fractions provided by the project team (i.e., CZ2A:55\%, CZ3A: 33\%, CZ3B: 11\% and CZ4B: 1\%). During the data collection period the City of Houston energy code was the 2009 IECC amended to be $15 \%$ more energy efficient than the published 2009 IECC. This amended code was in place from 2013 until adoption of the 2015 IECC on September 1, 2016.

Other results of interest, such as analysis based on climate zone level or reporting of non-key items, were also identified. While some of these items are visible in the publicly available data set, they should not be considered statistically representative.

\subsubsection{Determination of Compliance}

The field study protocol is based upon a single site visit, which makes it impossible to know whether a particular home complies with the energy code as not enough information can be gathered in a single visit to know whether all code requirements have been met. For example, homes observed during the earlier stages of construction often lack key features (e.g., ceilings with insulation), and in the later stages many of these items may be covered and therefore unobservable. To gather all the data required in the sampling plan, field teams therefore needed to visit homes in various stages of construction. The analytical implications of this are described above in Section 2.3.2.

\subsubsection{Sampling Substitutions}

As is often the case with field-based research, substitutions to the state sampling plan were sometimes needed to fulfill the complete data set. If the required number of observations in a jurisdiction could not be met because of a lack of access to homes or an insufficient number of homes (as can be the case in rural areas), substitute jurisdictions were selected by the project team. In all cases, the alternative selection was comparable to the original in terms of characteristics such as the level of construction activity and general demographics. More information on the sampling plan and any state-specific substitutions are discussed in Appendix B.

\subsubsection{Site Access}

Site access was purely voluntary, and data was collected only in homes where access was granted, which can be characterized as a self-selection bias. While every effort was made to limit this bias (i.e., sampling randomization, outreach to builders, reducing the burden of site visits, etc.), it is inherent due to the voluntary nature of the study. The impacts of this bias on the overall results are not known.

\subsubsection{Analysis Methods}

All energy analysis was conducted using prototype models; no individually visited homes were modeled, as the self-imposed, one-visit-per-home limitation meant that not all necessary modeling inputs could be collected from a single home. Thus, the impact of certain field-observable factors such as size, height, orientation, window area, floor-to-ceiling height, equipment sizing, and equipment efficiency were not included in the analysis. In addition, duct leakage was modeled separately from the other key items due to limitations in the EnergyPlus ${ }^{\mathrm{TM}}$ software used for analysis. It should also be noted that the resulting energy consumption and savings projections are based on modeled data, and not on utility bills or actual home energy usage. 


\subsubsection{Presence of Tradeoffs}

Field teams were able to gather only a minimal amount of data regarding which code compliance paths were being pursued for homes included in the study; all analyses therefore assumed that the prescriptive path was used. The project team agreed that this was a reasonable approach. The overall data set was reviewed in an attempt to determine if common tradeoffs were present, but the ability to do this was severely limited by the single site-visit principle which did not yield complete data sets for a given home. To the extent it could be determined, it did not appear that there was a systematic presence of tradeoffs. 


\subsection{State Results}

\subsection{Field Observations}

The key items form the basis of the study, and are therefore the focus of this section. Texas comprises multiple climate zones, but samples were only taken from climate zone 2 (CZ2). (See Section 2.4.1 Applicability of Results for more information on how the CZ2 samples were used in the statewide analysis.) A discussion of other findings is also covered in this section, including a description of how certain observations, such as insulation installation quality, are used to modify key item results. (See Section 2.3.1 for a sample graph and explanation of how they should be interpreted.) For Texas, the observations are compared to two codes; the red line represents the requirement of the 2009 IECC, and the black line represents the requirement of Texas' amended 2015 IRC - values to the right-hand side of this line are better than code.

\subsubsection{Key Items}

The field study and underlying methodology are driven by key items that have a significant direct impact on residential energy efficiency. The graphs presented in this section represent the key item results for the state based on the measures observed in the field. Note that these key items are also the basis of the results presented in the subsequent energy and savings phases of analysis.

The following key items were found applicable within the state:

1. Envelope tightness ( $\mathrm{ACH}$ at 50 Pascals)

2. Window SHGC

3. Window U-factor

4. Exterior wall insulation (assembly U-factor)

5. Ceiling insulation (R-value)

6. Lighting (\% high-efficacy)

7. Duct tightness (expressed in cfm per $100 \mathrm{ft}^{2}$ of conditioned floor area at 25 Pascals)

The predominant foundation type observed was slab-on-grade. Since Texas has no insulation requirement for slabs in CZ2 under either the 2009 IRC or 2015 Texas Energy Code, and because the project team specifically requested removal of the foundation insulation questions from the data collection form, foundation insulation is not included in this section. 


\subsubsection{Envelope Tightness}

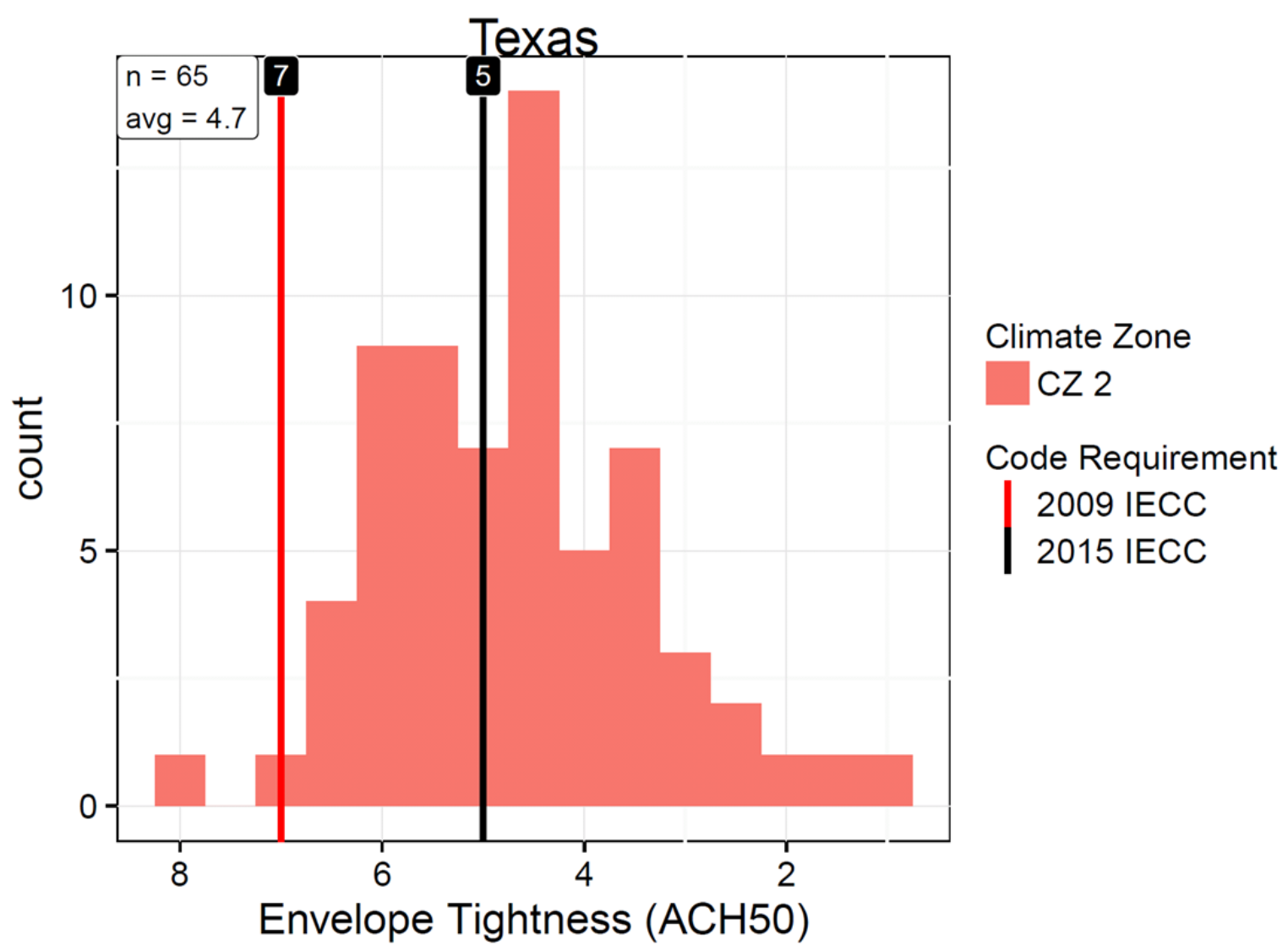

Figure 3.1. Envelope Tightness (ACH50)

- Observations:

- Number: 65

- Range: 7.9 to 1.2 ACH50

- Average: 4.7 ACH50

Table 3.1. Envelope Tightness (ACH50)

\begin{tabular}{ccc}
\hline Climate Zone and Code & CZ2 (2009 IECC) & CZ2 (2015 Texas Energy Code) \\
\hline Requirement & 7 & 5 \\
Compliance Rate & 63 of $65(97 \%)$ & 39 of $65(60 \%)$ \\
\hline
\end{tabular}

\section{- Interpretations:}

- Overall, the distribution exhibits lower air leakage than expected based on the 2009 IECC requirement and higher than expected for the 2015 Texas Energy Code.

- Nearly all of the observations met or exceeded the 2009 IECC requirements, and more than half of the observations met or exceeded the 2015 Texas Energy Code requirement. Most of the remaining observations were in the 5.11 to $5.91 \mathrm{ACH} 50$ range. 
- Reductions in envelope air leakage represent an area for improvement in the state, and should be given attention in future training and enforcement.

\subsubsection{Window SHGC}

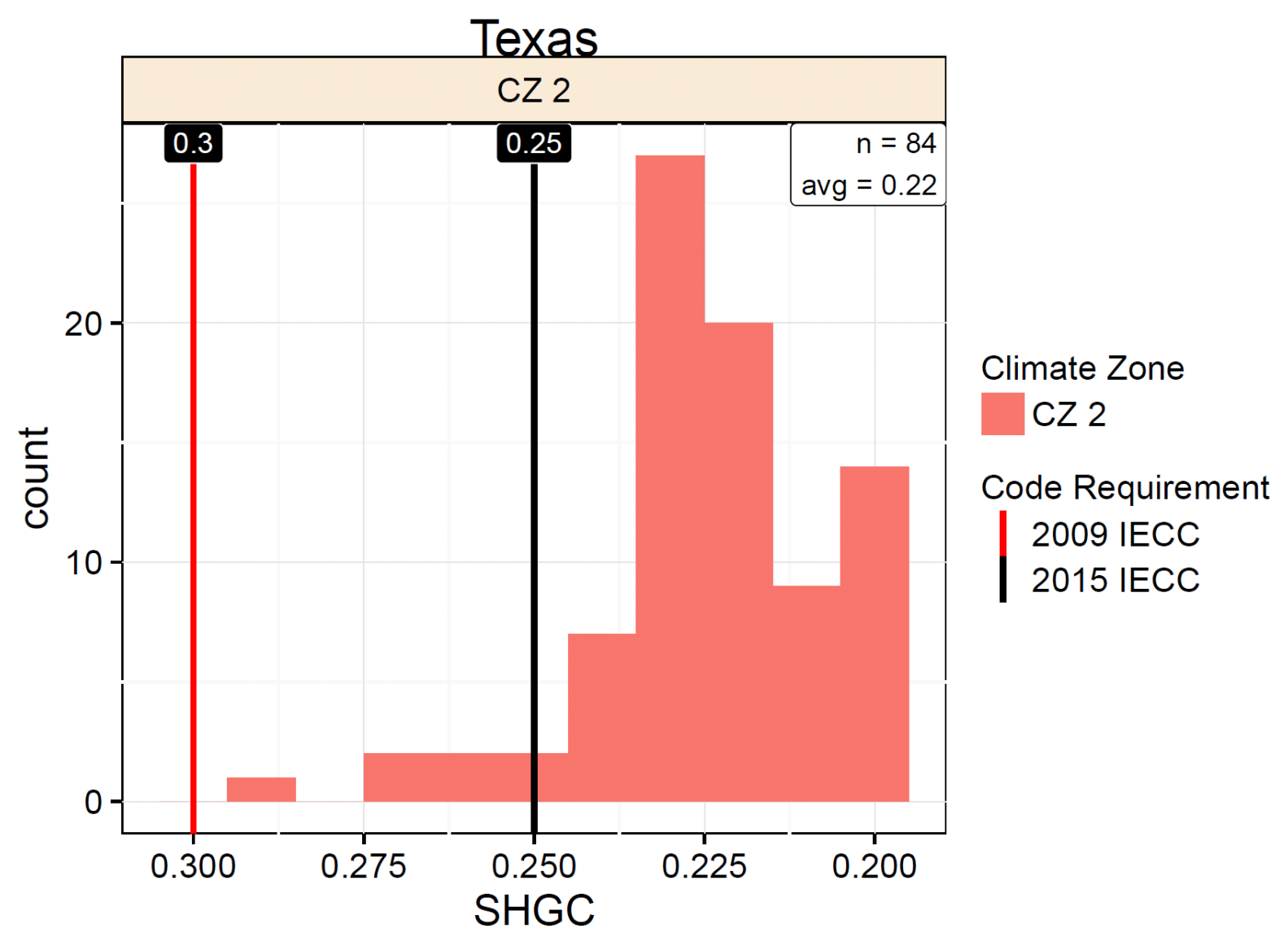

Figure 3.2. Window SHGC

- Observations:

- Number: 84

- Range: 0.29 to 0.20

- Average: 0.22

Table 3.2. Window SHGC

\begin{tabular}{ccc}
\hline Climate Zone and Code & CZ2 (2009 IECC) & CZ2 (2015 Texas Energy Code) \\
\hline Requirement & 0.30 & 0.25 \\
Compliance Rate & 84 of $84(100 \%)$ & 79 or $84(94 \%)$ \\
\hline
\end{tabular}




\section{- Interpretations:}

- SHGC values were very consistent, and all of the observations met the 2009 IECC requirement (and therefore also met the 2009 IRC requirement in CZ2 of 0.35) and nearly all also met the 2015 Texas Energy Code requirement.

- The vast majority of the observations were in the 0.23 to 0.20 SHGC range.

\subsubsection{Window U-Factor}

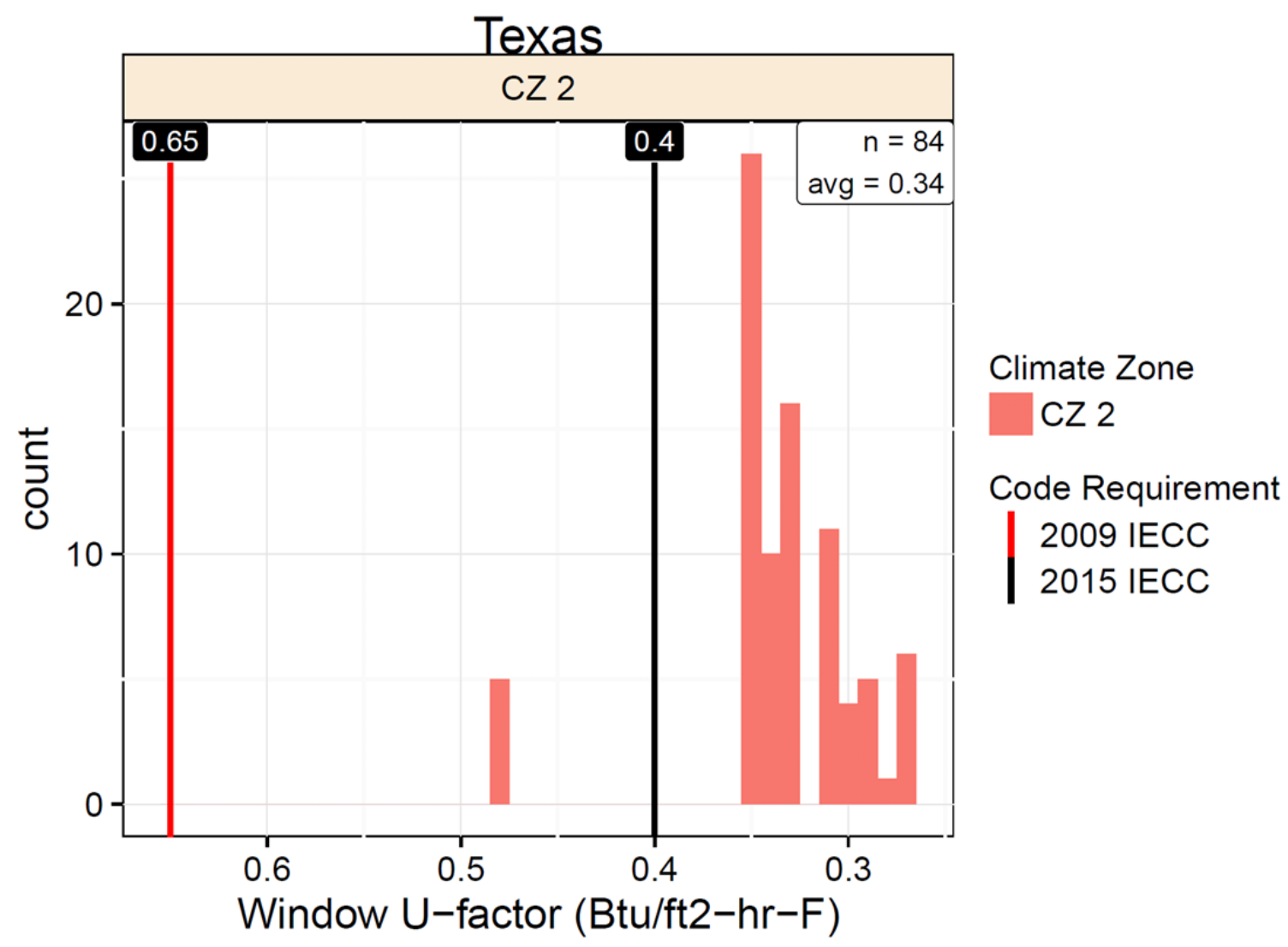

Figure 3.3. Window U-Factor

\section{- Observations:}

- Number: 84

- Range: 0.48 to 0.27

- Average: 0.34

Table 3.3. Window U-Factor

\begin{tabular}{ccc} 
Climate Zone and Code & CZ2 (2009 IECC) & CZ2 (2015 Texas Energy Code) \\
Requirement & 0.65 & 0.40 \\
Compliance Rate & 84 of $84(100 \%)$ & 79 of $84(94 \%)$ \\
\hline
\end{tabular}




\section{- Interpretations:}

- There is $100 \%$ compliance compared to the 2009 IECC requirement and nearly $100 \%$ compliance for fenestration products in the state against the 2015 Texas Energy Code.

- This represents one of the most significant findings of the field study, with nearly all of the observations at or above the code requirement.

- Window U-factor requirements appear to have been implemented with a high rate of success across the state.

\subsubsection{Wall Assemblies}

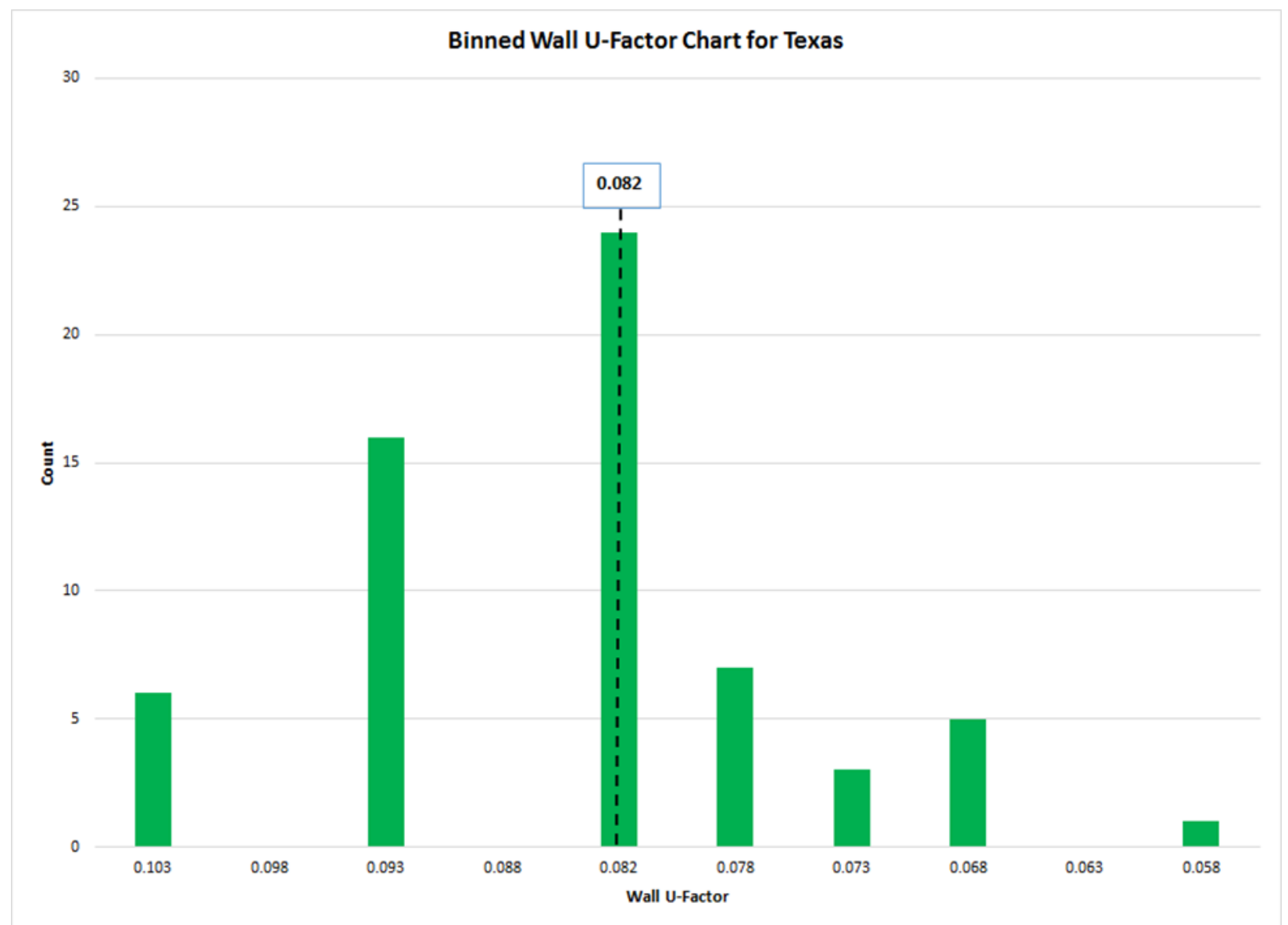

Figure 3.4. Texas Wall Assembly Performance, including Wall Insulation Installation Quality

Figure 3.4 combines all cavity R-value and wall insulation installation quality data observed in the state to generate an "effective U-factor" chart. A more detailed discussion of insulation installation quality is included at the end of the section (3.1.1).

\section{- Observations:}

- Number: 62

- Range: 0.103 to 0.058

- Average: 0.084 
Table 3.4. Frame Wall Assembly

\begin{tabular}{ccc}
\hline Climate Zone and Code & CZ2 (2009 IECC) & CZ2 (2015 Texas Energy Code) \\
\hline Assembly U-Factor (expected) & 0.082 & 0.082 \\
Rate & 40 of 62 (65\%) & 40 of $62(65 \%)$ \\
\hline
\end{tabular}

\section{- Interpretations:}

- Overall, nearly two-thirds of the observations comply with the code.

- Table 3.8 indicates that 38 of 62 wall assemblies (61\%) had an insulation installation quality of Grade I, but there is still room for improvement.

\subsubsection{Ceilings}

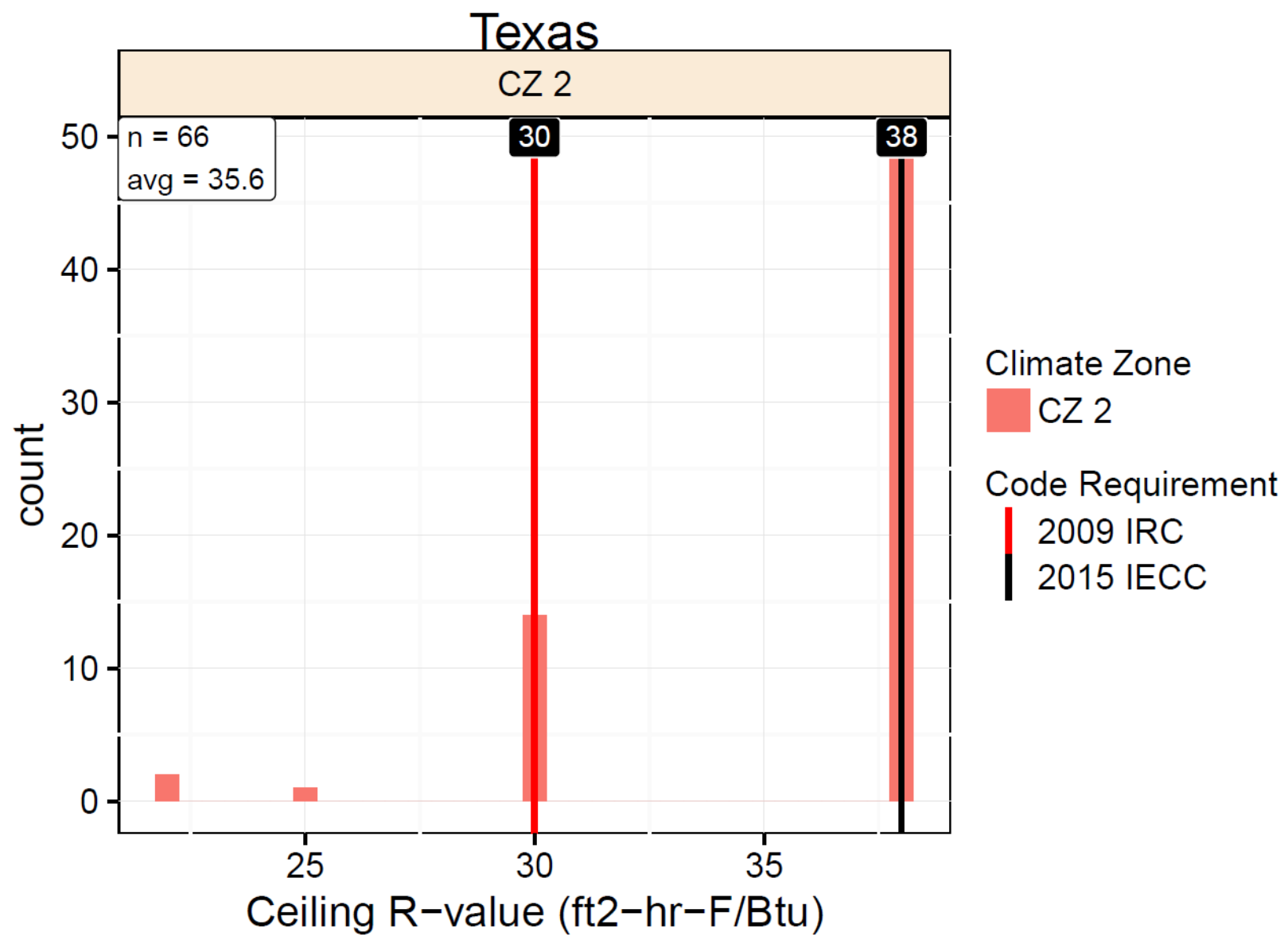

Figure 3.5. Ceiling R-Value

- Requirement: R-30 (CZ2) - 2009 IECC / R-38 (CZ2) - 2015 Texas Energy Code

- Observations:

- Number: 66

- Range: R-22 to R-38

- Average: R-35.6 
Table 3.5. Ceiling Insulation (R-Value)

\begin{tabular}{ccc}
\hline Climate Zone and Code & CZ2 (2009 IECC) & CZ2 (2015 Texas Energy Code) \\
\hline Requirement & R-30 & R-38 \\
Compliance Rate & 63 of 66 (95\%) & 49 of $66(74 \%)$ \\
\hline
\end{tabular}

\section{- Interpretations:}

- Nearly all the observations met or exceeded the 2009 requirement, and the majority of observations were Grade I for insulation installation quality.

- Over one-quarter of the observations did not meet the 2015 Texas Energy Code requirement, and there appears to be an opportunity for improvement.

\subsubsection{Lighting}

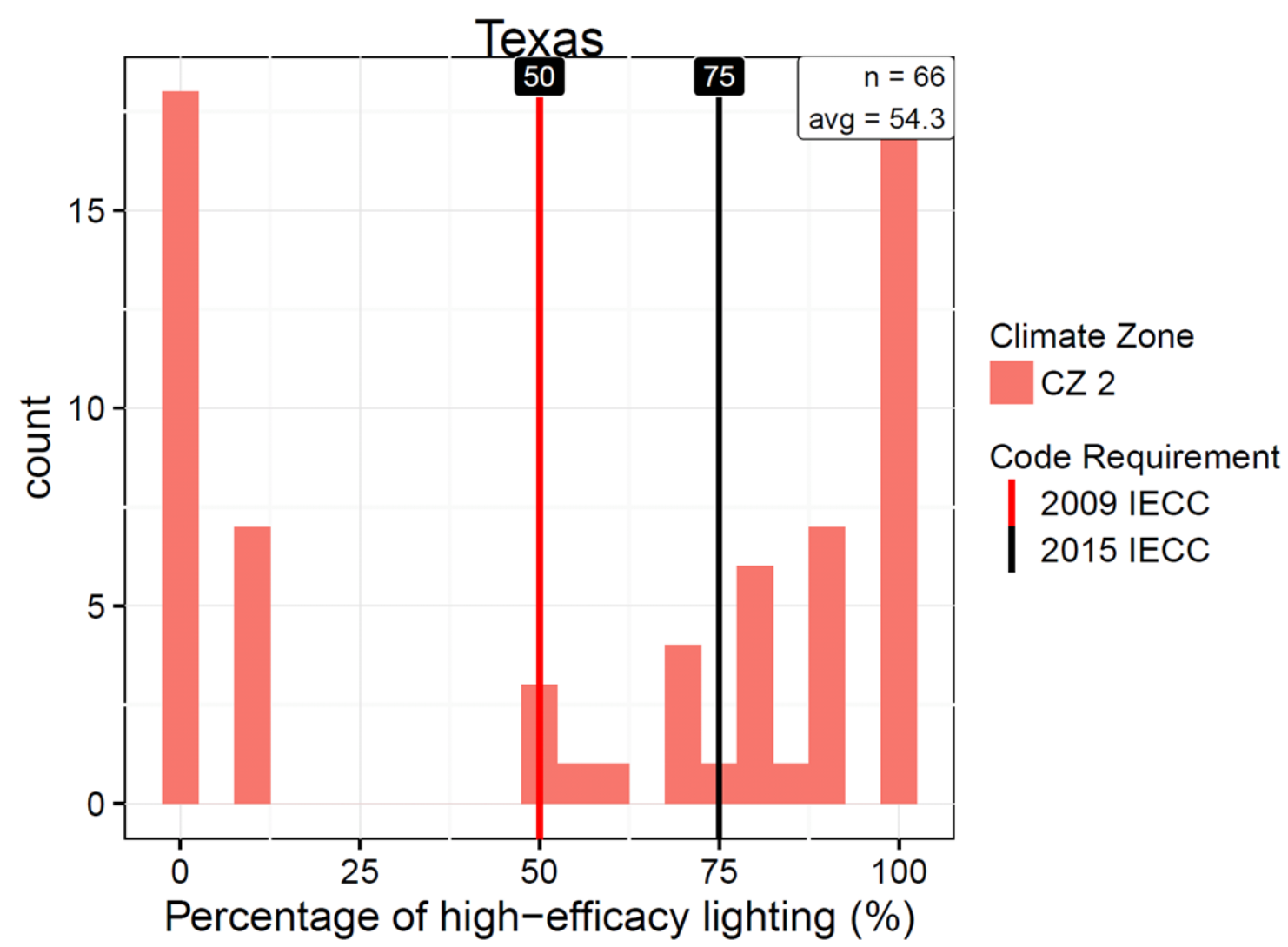

Figure 3.6. High-efficacy Lighting Percentage

\section{- Observations:}

- Number: 66

- Range: 0 to 100

- Average: 54.3 
Table 3.6. High-efficacy Lighting Percentage

\begin{tabular}{ccc}
\hline Climate Zone and Code & CZ2 (2009 IECC) & CZ2 (2015 Texas Energy Code) \\
\hline Requirement & 50 & 75 \\
Compliance Rate & 41 of $66(62 \%)$ & 32 of $66(48 \%)$ \\
\hline
\end{tabular}

- Interpretations:

- A little more than half of the field observations were observed to meet the 2009 IECC requirement, but less than half met the 2015 Texas Energy code; a much lower number than expected.

- The most common observations are in the 50-100\% range, but there were a significant quantity and wide range of non-compliant observations.

- This should be considered an area for increased attention in future training and enforcement within the state.

\subsubsection{Duct Tightness}

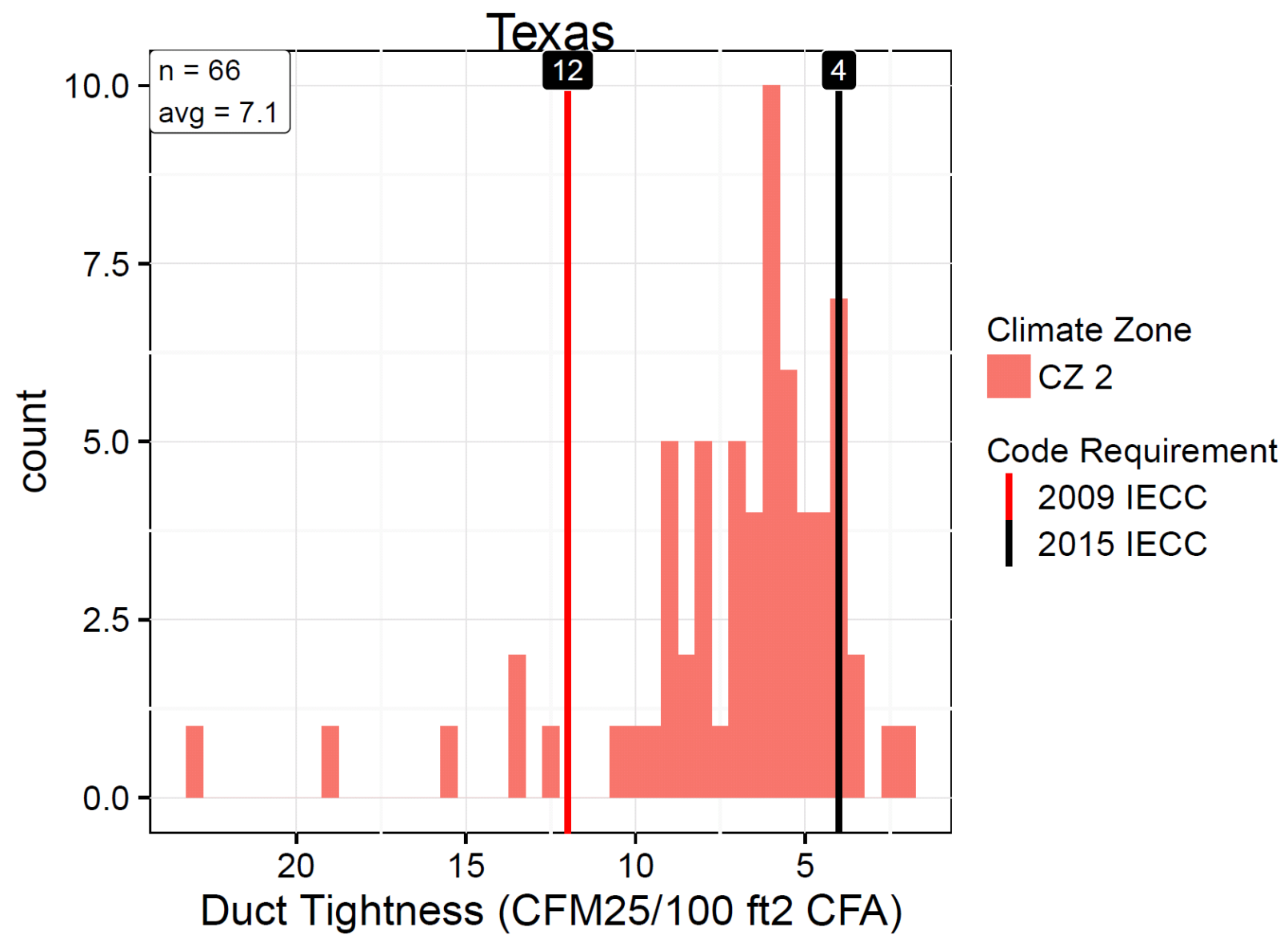

Figure 3.7. Duct Tightness (CFM25/100ft2 CFA)

\section{- Observations:}

- Number: 66 
- Range: 23 to 2

- Average: $7.1 \mathrm{CFM} 25 / 100 \mathrm{ft}^{2} \mathrm{CFA}$ (in unconditioned space); 5.7 for ducts in conditioned space

Table 3.7. Duct Tightness

\begin{tabular}{ccc}
\hline Climate Zone and Code & CZ2 (2009 IECC) & CZ2 (2015 Texas Energy Code) \\
\hline Requirement & 12 & 4 \\
Compliance Rate & 60 of $66(91 \%)$ & 12 of $66(18 \%)$ \\
\hline
\end{tabular}

- Interpretations:

- Overall the distribution exhibits lower leakage than expected compared to the 2009 IECC requirement, but much higher leakage than expected compared to the 2015 Texas Energy code requirement. ${ }^{22}$

- Reductions in duct leakage represent a significant area for improvement within the state under the 2015 code, and should be given increased attention in future training and enforcement.

Based on visual inspection, ducts were observed as sealed the vast majority of the time $(83 \%)$. This appears consistent with the testing results relative to the 2009 IECC requirement. However, while the code requires ducts, air handlers and filter boxes to be sealed, it does not provide a comprehensive list of inspection points (as it does with envelope air sealing, in comparison). It may be necessary to utilize more advanced sealing methods in order to meet the testing threshold required in the 2015 Texas Energy Code.

\subsubsection{Impact of Insulation Installation Quality}

At the start of the project, insulation installation quality was noted as a particular concern among project teams and stakeholders, as it plays an important role in the energy performance of envelope assemblies. Insulation installation quality was therefore collected by the field teams whenever possible, and applied as a modifier in the analyses for applicable key items (i.e., ceiling insulation, and wall insulation). Teams followed the RESNET ${ }^{23}$ assessment protocol which has three grades, Grade I being the best quality installation and Grade III being the worst.

Table 3.8 shows the insulation installation quality levels for framed envelope assemblies, as observed in the state. The majority of the observations (134 of 204) were classified as Grade I, indicating that insulation installation quality is generally good.

Table 3.8. Insulation Installation Quality

\begin{tabular}{ccccc}
\hline Assembly & Grade I & Grade II & Grade III & Total Observations \\
\hline Roof Cavity & 36 & 11 & 2 & 49 \\
Above Grade Wall & 38 & 19 & 5 & 62 \\
Knee Wall & 39 & 21 & 4 & 64 \\
\hline
\end{tabular}

${ }^{22}$ There were an additional 7 homes in the state sample with ducts located entirely within conditioned space. These leakage rates were not included in the energy analysis, and are therefore omitted from the above Duct Tightness graphic.

${ }^{23} \mathrm{See}$ http://www.resnet.us/standards/RESNET_Mortgage_Industry_National_HERS_Standards.pdf 


\subsubsection{Additional Data Items}

The project team collected data on all code requirements within the state as well as other areas to inform the energy simulation and analysis for the project (e.g., home size, installed equipment systems, etc.). While these items were not the focal point of the study, and many are not considered statistically representative, they do provide some insight surrounding the energy code and residential construction within the state.

The following represents a summary of this data and outlines some of the more significant findings, in many cases including the observation or compliance rate associated with the specified item. A larger selection of the additional data items collected as part of the state field study is contained in the Appendix. The full data set is also available on the DOE Building Energy Codes Program website. ${ }^{24}$ The percentages provided in the section below represent percentages of total observations or the percentage of observations that complied.

\subsubsection{Average Home}

- Size: $2708 \mathrm{ft}^{2}$ and 1.82 stories

\subsubsection{Compliance}

- All of the homes for which data were available were permitted under the 2009 IRC (89\%) or 2012 $\operatorname{IECC}(11 \%)$

- Approximately one quarter of the homes for which data were available (26\%) participated in an above-code program

- None of the homes which were participating in an above-code program reported the specific abovecode program

\subsubsection{Envelope}

- Profile:

- Walls: All were wood-framed walls with a mix of 4" (97\%) and 6" (3\%) studs

- Foundations: All homes were slab-on-grade

- Successes (percentage of compliant observations):

- Insulation labeled (97\%)

- IC-rated light fixtures sealed (98\%)

- Utility penetrations sealed (93\%)

- Areas for Improvement (percentage of compliant observations):

- Attic hatches \& doors complied (42\%)

- Dropped ceilings sealed (26\%)

- Knee walls sealed (67\%)

- Envelope areas behind bathroom tubs \& showers sealed (70\%)

${ }^{24}$ Available at https://www.energycodes.gov/compliance/residential-energy-code-field-study 


\subsubsection{Duct \& Piping Systems}

- Profile:

- Ducts were not generally located within conditioned space (percentage of duct system):

○ Supply: $34 \%$

○ Return: $34 \%$

- About 5\% of homes (7 homes) located supply ducts entirely within conditioned space

- About $7 \%$ of homes ( 9 homes) located return ducts entirely within conditioned space

- Successes (percentage of compliant observations):

- Building cavities not used as ducts (100\%)

- Air handlers (90\%) and filter boxes (90\%) sealed

- Areas for Improvement (percentage of compliant observations):

- $\quad$ Air ducts sealed (83\%)

\subsubsection{HVAC Equipment}

- Profile:

- Heating: Mostly gas furnaces with an average efficiency of 83 AFUE.

- Cooling: Mostly central AC with an average efficiency of 15.1 SEER

- Water Heating: Mostly gas storage (85\%) with an average capacity of 54 gallons and average efficiency rating of EF 0.65

- Ventilation: Majority exhaust-only (84\%) or AHU-integrated (16\%). None of the homes had a dedicated exhaust fan - all relied solely upon the bathroom fan.

\section{- Successes (percentage of compliant observations):}

- User manuals for mechanical systems provided (100\%)

\subsection{Energy Intensity}

The statewide energy analysis results are shown in the figures below, which compare the weighted average energy consumption of the observed data set to the weighted average consumption based on the state energy code. The observed data set (as gathered in the field) was compared against the same set of homes meeting prescriptive code requirements. In terms of overall energy consumption, homes within the state appear to use less energy relative to the previous 2009 IECC, $21.08 \mathrm{kBtu} / \mathrm{ft}^{2}$-yr statewide compared to $25.94 \mathrm{kBtu} / \mathrm{ft}^{2}$ (Figure 3.8), but more than the current minimum state code requirements, $25.6 \mathrm{kBtu} / \mathrm{ft}^{2}$ compared to $22.6 \mathrm{kBtu} / \mathrm{ft}^{2}$ (Figure 3.9). This suggests that on average the typical home EUI in the state is about $19 \%$ better than the 2009 code and about $13 \%$ worse than the current Texas energy code.

In the analysis for the 2009 IECC, it was assumed that all homes performed as though they were in CZ2 (Figure 3.8). For the 2015 Texas Energy Code analysis, it was assumed that all homes were constructed as observed in $\mathrm{CZ2}$, but that the performance of the homes varied by climate zone (Figure 3.9). The project team requested the additional level of detail for the 2015 Texas Energy Code as that is the current code. 


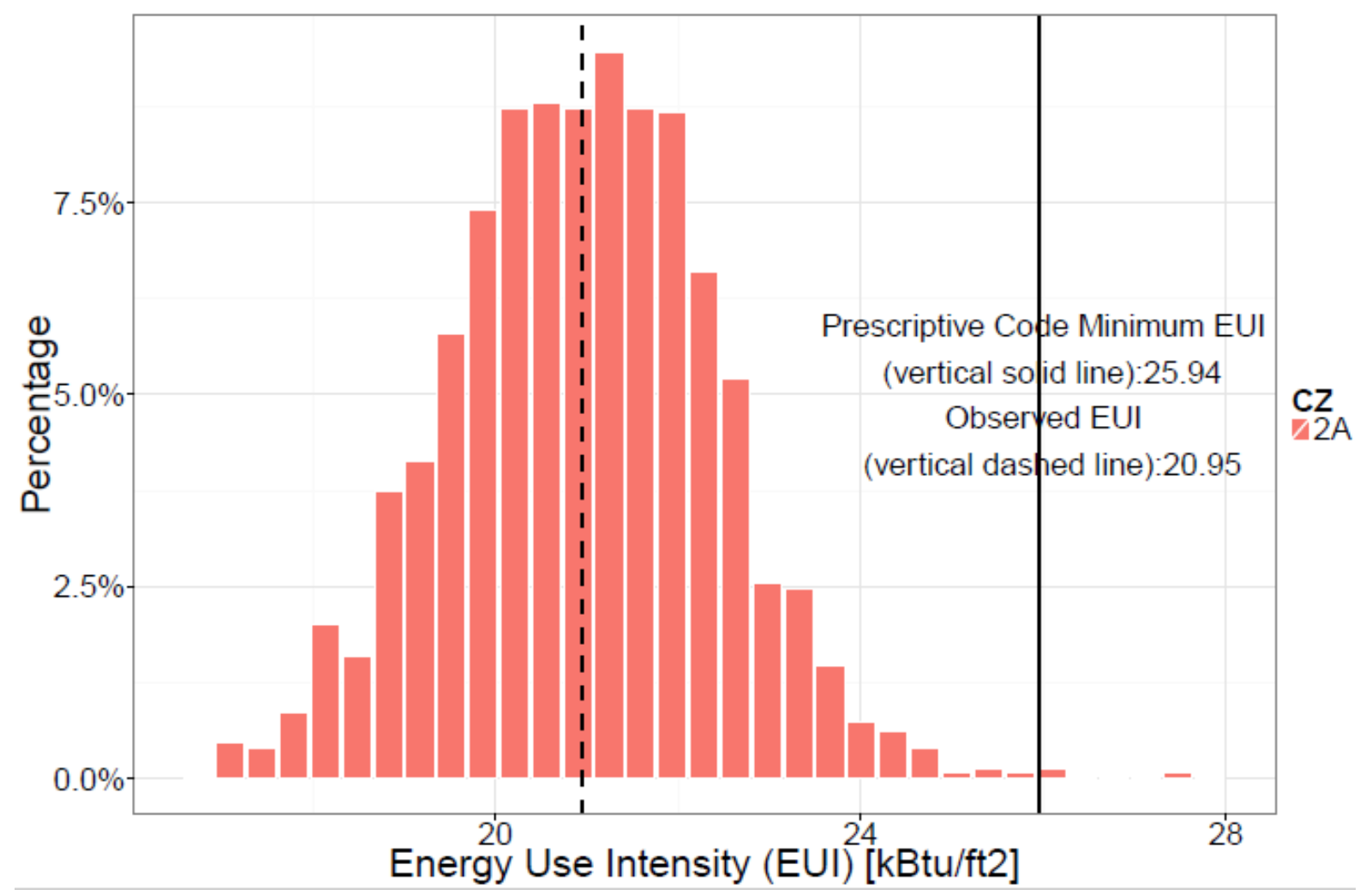

Figure 3.8. Statewide EUI Analysis for Texas (2009 IECC)

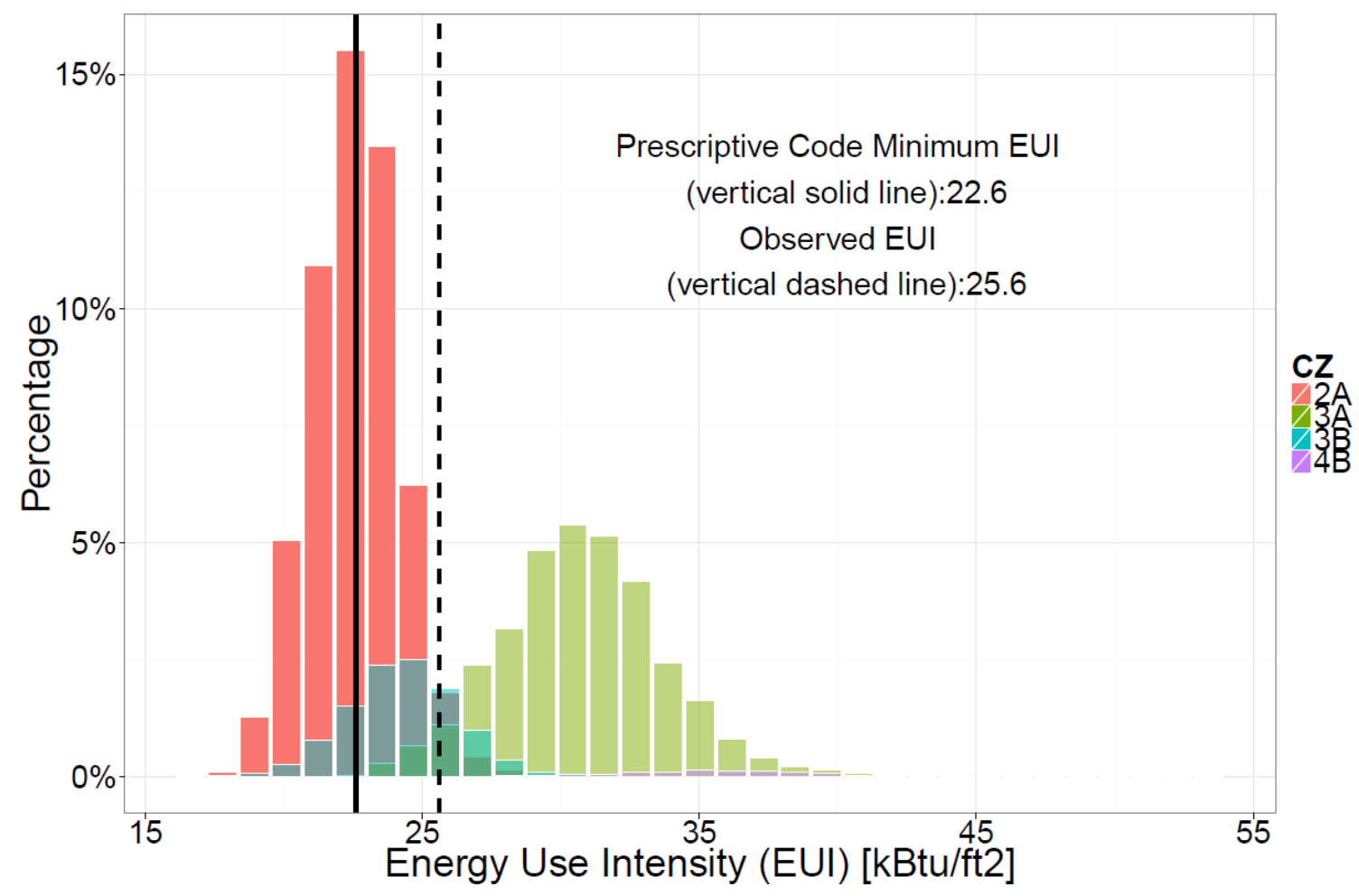

Figure 3.9. Statewide EUI Analysis for Texas (2015 TX Code) 


\subsection{Savings Potential}

Most data in this study was collected from homes permitted under the 2009 code $^{25}$; potential savings, however, were calculated against the 2009 code and also against the 2015 code. Several key items exhibit the potential for improvement, although the specific key items vary by code. Due to the EUI results noted in the previous section, there were less savings opportunities when compared to the 2009 code, although some savings do exist for envelope air leakage, lighting, exterior wall insulation, and duct leakage. However, the current code is the 2015 Texas code, which is the basis of the savings noted in Table 3.9 and Table 3.10 .

Those key items with the greatest potential ${ }^{26}$, shown below followed by the percent of observations that met or exceeded the associated code requirement, were analyzed further to calculate the associated savings potential, including energy, cost and carbon savings.

- Envelope Air Leakage (60\%),

- Exterior Wall Insulation (65\%),

- Duct Leakage (18\%),

- Lighting (48\%), and

- Ceiling Insulation (74\%).

For analytical details refer to Section 2.3.3 (Savings Analysis) or the methodology report (2016).

Estimated annual (one-year) savings resulting from the analysis are shown below in order of highest to lowest total energy, cost and carbon savings (Table 3.9). As can be seen, there are significant savings opportunities, with the greatest total savings potential associated with these measures. In addition, Table 3.10 shows the total savings and emissions reductions that will accumulate over 5,10 , and 30 years of construction.

Table 3.9. Statewide Annual Measure-Level Savings for Texas (2015 TX Code)

\begin{tabular}{lccccccc}
\hline & $\begin{array}{c}\text { Electricity } \\
\text { Savings } \\
\text { (kWh/ } \\
\text { home) }\end{array}$ & $\begin{array}{c}\text { Natural } \\
\text { Gas Savings } \\
\text { (therms/ } \\
\text { home) }\end{array}$ & $\begin{array}{c}\text { Total } \\
\text { Savings } \\
\text { (kBtu/ } \\
\text { home) }\end{array}$ & $\begin{array}{c}\text { Number } \\
\text { of Homes }\end{array}$ & $\begin{array}{c}\text { Total } \\
\text { Energy } \\
\text { Savings } \\
\text { Measure }\end{array}$ & $\begin{array}{c}\text { Total } \\
\text { Energy } \\
\text { Cost } \\
\text { Savings (\$) }\end{array}$ & $\begin{array}{c}\text { Total State } \\
\text { Emissions } \\
\text { Reduction } \\
\text { (MT } \\
\text { CO2e) }\end{array}$ \\
\hline $\begin{array}{l}\text { Envelope } \\
\text { Air Leakage }\end{array}$ & 162 & 26 & 3130 & 100,608 & 314,889 & $4,656,869$ & 24,969 \\
$\begin{array}{l}\text { Exterior } \\
\begin{array}{l}\text { Wall } \\
\text { Insulation }\end{array}\end{array}$ & 241 & 21 & 2913 & 100,608 & 293,040 & $5,029,864$ & 27,865 \\
$\begin{array}{l}\text { Duct } \\
\text { Leakage }\end{array}$ & 210 & 11 & 1801 & 100,608 & 181,188 & $3,582,893$ & 20,371 \\
$\begin{array}{l}\text { Lighting } \\
\text { Ceiling }\end{array}$ & 261 & -2 & 701 & 100,608 & 70,571 & $2,774,421$ & 17,100 \\
$\begin{array}{l}\text { Insulation } \\
\text { TOTAL }\end{array}$ & 24 & 2 & 235 & 100,608 & 23,677 & 443,058 & 2,496 \\
\hline
\end{tabular}

${ }^{25}$ Some homes in the Houston area were permitted under the 2012 IECC.

${ }^{26}$ Defined here as those items with less than $85 \%$ of observations meeting the prescriptive code requirement 
Table 3.10. Five-years, Ten-years, and Thirty-years Cumulative Annual Statewide Savings for Texas (2015 TX Code)

\begin{tabular}{lccccccccc}
\hline \multirow{2}{*}{ Measure } & \multicolumn{2}{c}{ Total Energy Savings (MMBtu) } & \multicolumn{2}{c}{ Total Energy Cost Savings (\$) } & \multicolumn{3}{c}{ Total State Emissions Reduction } \\
(MT CO2e)
\end{tabular}




\subsection{Conclusions}

The Texas field study provides an enhanced understanding of statewide code implementation, and suggests that high levels of compliance were achieved relative to the former state energy code (2009 IRC). During the course of the study, the state updated its energy code, with the new code based on the 2015 IRC (with Texas amendments). As a result, the project team requested that the analysis be done not only against the former statewide code, the 2009 IRC, but also the new 2015 Texas Energy Code. This report contains findings relative to both codes, which help portray levels of compliance under the former code, as well as potential savings the state will realize by achieving full compliance with the updated energy code.

Significant savings can be achieved in the state through increased compliance with the 2015 Texas Energy Code. Potential statewide annual energy savings are 883,365 MMBtu, which equates to $\$ 16,487,105$ in cost savings, and emission reductions of 92,801 MT CO2e. Over a 30-year period, these impacts grow to 410 trillion Btu, $\$ 7.66$ billion, and over 43 MT CO2e in avoided emissions.

Several key measures directly contribute to these savings, and should be targeted through future education, training and outreach activities. The savings associated with each are found in Table 4.1.

Table 4.1. Annual Statewide Savings Potential in Texas (2015 TX Code)

\begin{tabular}{llccc}
\hline & \multirow{2}{*}{ Key Measure } & \multicolumn{3}{c}{ Annual Savings } \\
\cline { 3 - 5 } & & Energy $($ MMBtu) & Cost $(\$)$ & Carbon $($ MT CO2e) \\
\hline 1 & Envelope Air Leakage & 314,889 & $4,656,869$ & 24,969 \\
2 & Exterior Wall Insulation & 293,040 & $5,029,864$ & 27,865 \\
3 & Duct Leakage & 181,188 & $3,582,893$ & 20,371 \\
4 & Lighting & 70,571 & $2,774,421$ & 17,100 \\
5 & Ceiling Insulation & 23,677 & 443,058 & 2,496 \\
\hline Total & & $\mathbf{8 8 3 , 3 6 5}$ MMBtu & $\mathbf{\$ 1 6 , 4 8 7 , 1 0 5}$ & $\mathbf{9 2 , 8 0 1}$ MT CO2e \\
\hline
\end{tabular}

When compared to the 2009 IECC, the average home in Texas uses about $19 \%$ less energy than a home exactly meeting the code. The average home uses about $13 \%$ more energy than a home exactly meeting the new state energy code, the 2015 Texas Energy Code. In terms of particular measures, fenestration (U-factor \& SHGC) was better than code across the board, with the average window exceeding the requirement of any U.S. climate zone. Other measures had varying degrees of savings potential. 



\subsection{References}

Census Bureau. 2016. Censtats Building Permits Database. http://censtats.census.gov/

DOE. 2012. National Energy and Cost Savings for New Single- and Multifamily Homes: A Comparison of the 2006, 2009, and 2012 Editions of the IECC, available at http://www.energycodes.gov/development

DOE Building Energy Codes Program's residential field study website is available at https://www.energycodes.gov/compliance/residential-energy-code-field-study (accessed August 1, 2016).

DOE/PNNL 2016. "Residential Energy Code Field Study: Data Collection and Analysis." Available at https://www.energycodes.gov/compliance/residential-energy-code-field-study

EnergyPlus. https://energyplus.net/.

The Texas residential field study website is available at https://eepartnership.org/program-areas/energycodes/houston-field-study/ (accessed August 1, 2016).

Residential Energy Services Network. 2013. "Mortgage Industry National Home Energy Rating System Standards.” Residential Energy Services Network, Oceanside, CA. www.resnet.us. 



\section{Appendix A}

\section{Stakeholder Participation}





\section{Appendix A}

\section{Stakeholder Participation}

Table A.1. Stakeholder Participation in Project Kickoff Meeting

\begin{tabular}{ll}
\hline \multicolumn{1}{c}{ Stakeholder } & \multicolumn{1}{c}{ Description } \\
\hline $\begin{array}{l}\text { TX State Energy Conservation Office } \\
\text { (SECO) }\end{array}$ & $\begin{array}{l}\text { Key state agency responsible for regulating code adoption and } \\
\text { compliance in Texas. SECO manages and allocates resources for } \\
\text { training and outreach regarding codes. }\end{array}$ \\
$\begin{array}{l}\text { Electric Utility Marketing Managers of } \\
\text { Texas (EUMMOT) }\end{array}$ & $\begin{array}{l}\text { The industry group that oversees the development and } \\
\text { implementation of energy efficiency programs and incentives for } \\
\text { investor owned electric utilities in TX }\end{array}$ \\
$\begin{array}{l}\text { International Code Council local chapters, } \\
\text { Brazos Valley Inspectors' Association, Bay } \\
\text { Area Inspectors' Association, Bluebonnet } \\
\text { Inspectors' Association and Golden Triangle }\end{array}$ & $\begin{array}{l}\text { Represent building officials in the TX Field Study area and act as } \\
\text { the anchors for the Regional Working Groups. Regional Working } \\
\text { Inspectors' Association }\end{array}$ \\
$\begin{array}{l}\text { generally provided promotion and support for the project. } \\
\text { Greater Houston Home Builders' }\end{array}$ & $\begin{array}{l}\text { The organization that represents a large number of the } \\
\text { homebuilders who participated in the Field Study }\end{array}$ \\
\hline
\end{tabular}





\section{Appendix B}

\section{State Sampling Plan}





\section{Appendix B}

\section{State Sampling Plan}

\section{B.1 State Sampling Plan}

Table B.1. State Sampling Plan

\begin{tabular}{lcc}
\hline \multicolumn{1}{c}{ Location } & Sample & Actual \\
\hline Harris County Unincorporated Area, Harris & 13 & 13 \\
Fort Bend County Unincorporated Area, Fort Bend & 5 & 5 \\
Montgomery County Unincorporated Area, Montgomery & 3 & 3 \\
Houston, Harris & 17 & 17 \\
Pearland, Brazoria & 5 & 6 \\
League City, Galveston & 3 & 4.5 \\
College Station, Brazos & 2 & 2 \\
Fulshear, Fort Bend & 1 & 1 \\
Conroe, Montgomery & 2 & 2 \\
Beaumont, Jefferson & 3 & 2 \\
Galveston, Galveston & 1 & 3 \\
Port Arthur, Jefferson & 1 & 1 \\
Texas City, Galveston & 1 & 1.5 \\
Baytown, Harris & 1 & 1 \\
Katy, Harris & 1 & 1 \\
Alvin, Brazoria & 1 & 1 \\
Dickinson, Galveston & 1 & 0 \\
Lumberton, Hardin & 1 & 2 \\
Pasadena, Harris & 1 & 0 \\
\hline Total & $\mathbf{6 3}$ & $\mathbf{6 6}$ \\
\hline
\end{tabular}

\section{B.2 Substitutions}

Several locations targeted by the original sampling plan (as illustrated in Table B.1 above) could not be met due to a lack of either available homes or builder cooperation. For each of these locations, alternatives (listed below) were determined to have the same socioeconomic and demographic characteristics. The project team, following DOE guidelines on substitutions, consolidated the alternatives and considered them as one location for sampling purposes. The numbers in parentheses repeat the data in the "Sample" and "Actual" column in Table B. $1^{1}$ to illustrate what was originally targeted compared to what was successfully collected:

- Beaumont (3/2), Lumberton (1/2)

\footnotetext{
${ }^{1}$ A partial sample (e.g., 1.5) indicates that not all of the key items were collected.
} 
- Pasadena (1/0), Pearland (5/6)

- Galveston (1/3), League City (3/4.5), Texas City (1/1.5) 
Appendix C

\section{Additional Data}





\section{Appendix C}

\section{Additional Data}

\section{C.1 Additional Data Collected by Field Teams}

The project team made observations on several energy efficiency measures beyond the key items alone. The majority of these additional items are based on code requirements within the state, while others were collected to inform the energy simulation and analysis for the project (e.g., installed equipment, whether the home participated in an above-code program, etc.). While these items were not the focal point of the study, and many are not considered statistically representative, they do provide some additional insight surrounding the energy code and residential construction within the state.

The following is a sampling of the additional data items collected as part of the Texas field study. Each item is presented, along with a brief description and statistical summary based on the associated field observations. The full data set is available on the DOE Building Energy Codes Program website. ${ }^{1}$

\section{C.1.1 General}

The following represents the general characteristics of the homes observed in the study:

\section{C.1.1.1 Average Home}

- Size (n=121): $2708 \mathrm{ft}^{2}$

- Number of Stories $(\mathrm{n}=130): 1.8$

Table C.1. Conditioned Floor Area $\left(\mathrm{ft}^{2}\right)$

\begin{tabular}{cccccc}
\hline Conditioned Floor Area $\left(\mathrm{ft}^{2}\right)$ & $<1000$ & 1000 to 1999 & 2000 to 2999 & 3000 to 3999 & $4000+$ \\
\hline Percentage & $1 \%$ & $21 \%$ & $49 \%$ & $22 \%$ & $7 \%$ \\
\hline
\end{tabular}

Table C.2. Number of Stories

\begin{tabular}{ccccc}
\hline No. of Stories & 1 & 2 & 3 & $4+$ \\
\hline Percentage & $39 \%$ & $39 \%$ & $22 \%$ & $0 \%$ \\
\hline
\end{tabular}

\section{C.1.1.2 Wall Profile}

- Framing Type $(\mathrm{n}=125)$ :

- Almost all were framed construction (99\%)

- Framing Material ( $\mathrm{n}=132)$ :

- $\operatorname{Wood}(100 \%)$

\footnotetext{
${ }^{1}$ Available at https://www.energycodes.gov/compliance/residential-energy-code-field-study
} 
- Steel $(0 \%)$

- Framing Depth ( $\mathrm{n}=133)$ :

- 4" (97\%)

- 6" $(3 \%)$

- Type of Wall Insulation ( $\mathrm{n}=62)$

- Cavity Only (81\%)

- Cavity + Continuous (19\%)

- Continuous Only (0\%)

\section{C.1.1.3 Foundation Profile}

- Foundation Type (n=133):

- Basement (0\%)

- Slab on Grade (100\%)

- Crawlspace $(0 \%)$

\section{C.1.1.4 Builder Profile}

- Average number of Homes Built Annually ( $n=36)$ : 61 homes

Table C.3. Number of Homes Built by Builder (annually)

\begin{tabular}{ccccc}
\hline No. of Homes per Year & $<10$ & 10 to 50 & 50 to 99 & $100+$ \\
\hline Percentage & $3 \%$ & $28 \%$ & $61 \%$ & $8 \%$ \\
\hline
\end{tabular}

\section{C.1.2 Compliance}

The following summarizes information related to compliance, including the energy code associated with individual homes, whether the home was participating in an above-code program, and which particular programs were reported. The percentages provided in the sections below represent percentages of total observations or the percentage of observations that complied.

\section{C.1.2.1 Energy Code Used $(n=38)$ :}

Table C.4. Energy Code Used

\begin{tabular}{ccc}
\hline Energy Code & 2009 IECC & 2012 IECC \\
\hline Percentage & $89 \%$ & $11 \%$ \\
\hline
\end{tabular}

- Was the home participating in an above-code program $(\mathrm{n}=35)$ ?

- Yes $(26 \%)^{*}$

- No $(74 \%)$ 
* No specific above-code programs were reported

\section{C.1.3 Envelope}

The following list of questions focus on average characteristics of the thermal envelope:

\section{C.1.3.1 Insulation Labels}

- Was insulation labeled $(n=75)$ ?

- Yes $(97 \%)$

$-\quad$ No $(3 \%)$

\section{C.1.3.2 Ceilings}

- Did the attic hatch/door exhibit the correct insulation value $(\mathrm{n}=50)$ ?

$-\quad$ Yes $(42 \%)$

- No $(58 \%)$

\section{C.1.3.3 Air Sealing ${ }^{1}$}

The following questions indicate whether sealing was completed in accordance with the checklist and associated code requirements:

- Thermal envelope sealed $(\mathrm{n}=82)(74 \%)$

- Fenestration sealed $(\mathrm{n}=53)(96 \%)$

- Openings around windows and doors sealed $(n=83)(96 \%)$

- Utility penetrations sealed $(\mathrm{n}=101)(93 \%)$

- Dropped ceilings sealed ( $\mathrm{n}=70)(74 \%)$

- Knee walls ( $\mathrm{n}=73)$ sealed (67\%)

- Garage walls and ceilings sealed $(n=51)(92 \%)$

- Tubs and showers sealed $(\mathrm{n}=83)(82 \%)$

- Attic access openings sealed $(n=55)(82 \%)$

- Rim joists sealed ( $\mathrm{n}=70)(87 \%)$

- Other sources of infiltration sealed $(n=89)(71 \%)$

- IC-rated light fixtures sealed ( $\mathrm{n}=98)(98 \%)$

\footnotetext{
${ }^{1}$ Note that results in this section are from checklist items that are addressed via visual inspection. When comparing these visual results with the actual tested results, it is clear that there can be significant differences in the two methods.
} 


\section{C.1.4 Duct \& Piping Systems}

The following represents an average profile of observed air ducting and water piping systems, followed by a list of additional questions related to such systems:

\section{C.1.4.1 System Profile}

- Duct Location in Conditioned Space (percentage):

- Supply (n=134): 34\% (7 homes with systems located entirely within conditioned space)

- Return (n=134): 34\% (9 homes with systems located entirely within conditioned space)

- Duct Insulation (R-value):

- Supply $(\mathrm{n}=12): 6$

- Return $(\mathrm{n}=11): 6$

- Ducts in Attics (R-value):

- Supply (n=128): 6.1 (0 homes observed to have no attic duct insulation)

- Return (n=128): 6.1 (0 homes observed to have no attic duct insulation)

- Pipe Insulation (R-value) ( $\mathrm{n}=126)$ :

- R-2 (29\%)

- R-3 (71\%)

- Building cavities not used as ducts ( $\mathrm{n}=113)(100 \%)$

- Air ducts sealed $(n=111)(83 \%)$

- Air handlers sealed ( $n=129)(90 \%)$

- Filter boxes sealed $(\mathrm{n}=129)(90 \%)$

\section{C.1.5 HVAC Equipment}

The following represents an average profile of observed HVAC equipment, followed by:

\section{C.1.5.1 Heating}

- Fuel Source $(n=124)$ :

- Gas $(89 \%)$

- Electricity (11\%)

- System Type ( $\mathrm{n}=122)$ :

- Furnace (95\%)

- Heat Pump (5\%)

- Average System Capacity ( $\mathrm{n}=77)$ :

- Furnace: 83,000 Btu

- Heat Pump: 54,000 Btu 
- Average System Efficiency ( $\mathrm{n}=122)$ :

- Furnace: 83 AFUE (all observed furnaces had an efficiency of 80 AFUE or better)

- Heat Pump: 8.8 HSPF

\section{C.1.5.2 Cooling}

- System Type ( $\mathrm{n}=116)$ :

- Central AC (94\%)

- Heat Pump (5\%)

- $\quad$ Room AC (1\%)

- Average System Capacity $(n=73)$ :

- $52,700 \mathrm{Btu}$

- Average System Efficiency $(\mathrm{n}=60)$ :

- $\quad$ 15.1 SEER (observations ranged from 13 to 18.5 SEER)

\section{C.1.5.3 Water Heating}

- Fuel Source $(\mathrm{n}=115)$ :

- Gas $(94 \%)$

- Electric $(6 \%)$

- System Type ( $n=114)$ :

- Storage $(91 \%)$

- Tankless $(9 \%)$

- System Capacity ( $\mathrm{n}=102)$ :

- Average Storage: 54 gallons (observations ranged from 40 to 100 gallons)

Table C.5. Water Heating System Storage Capacity Distribution

\begin{tabular}{ccccccc}
\hline Capacity & $<50$ gal & $50-59$ gal & $60-69$ gal & $70-79$ gal & $80-89$ gal & $90+$ gal \\
\hline Percentage & $26 \%$ & $53 \%$ & $0 \%$ & $0 \%$ & $18 \%$ & $3 \%$ \\
\hline
\end{tabular}

- Average System Efficiency ( $\mathrm{n}=69)$ :

- Electric Storage: EF 0.86

- Gas Storage: EF 0.63

- Gas Tankless: EF 0.69

\section{C.1.5.4 Ventilation}

- System Type ( $\mathrm{n}=101)$ :

- Exhaust Only (84\%) 
- AHU-Integrated (16\%)

- Exhaust Fan Type (n=85):

- Dedicated Exhaust (0\%)

- Bathroom Fan (100\%)

\section{C.1.5.5 Other}

- Mechanical manuals provided ( $\mathrm{n}=33)(100 \%)$ 



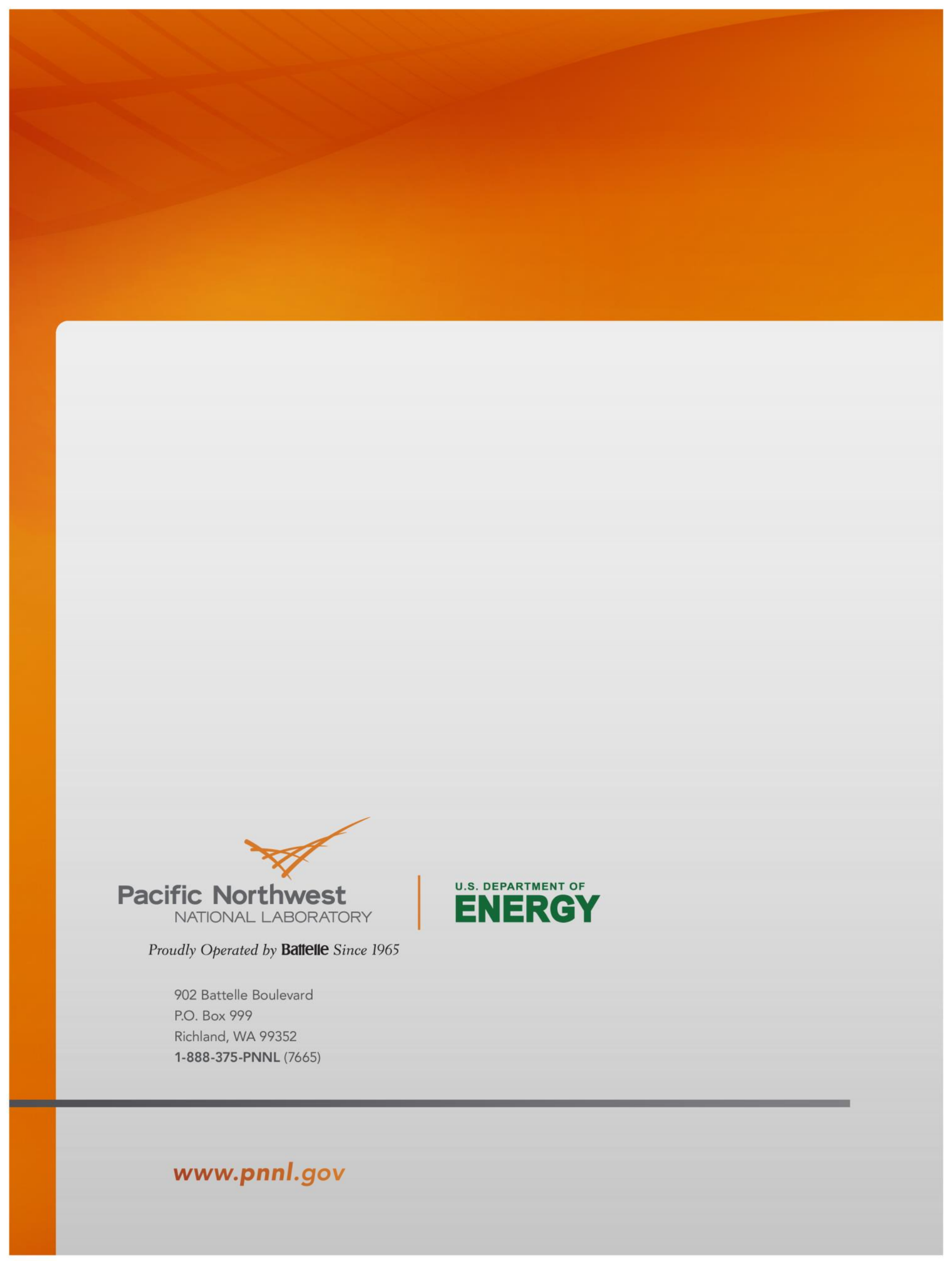

